\title{
THE ALUMINUM RECTIFIER ${ }^{1}$
}

\section{BY S. BARCLAY CHARTERS}

The most satisfactory theory of the aluminum rectifier is that given by Taylor and Inglis. ${ }^{2}$ They found the same results with a platinum anode covered with a film of aluminum hydroxide as with an aluminum anode. This apparently eliminates from consideration any effect due to the metal as such. Measurements made with an aluminum anode in sulphuric acid solution led to the following statements:

"These experiments show that the presence of certain ions, even in small concentration, enables a large current to pass through the cell. It seems probable, therefore, that the reason for the peculiar action of the aluminum is that the film of hydroxide with which the anode is covered is permeable to certain ions, but impermeable to others. ${ }^{3}$ If this is so, any anion which can readily pass through the film will enable a current to pass, while anions which cannot readily pass through will not enable it to do so. The anomalous behavior in $\mathrm{H}_{2} \mathrm{SO}_{4}$ would then be due to the impermeability of the film to $\mathrm{SO}_{4}^{\prime \prime}$ ions, and also to Al ${ }^{\cdots}$ ions. This explanation is also in accord with the fact that reversal of the current immediately causes current to pass through the cell, this being due to the permeability of the film to $\mathrm{H} \cdot$ ions, for it is difficult to suppose that reversal of the current immediately removes the film, and subsequent reversal immediately restores it.

"The surface of the aluminum electrode, when formed, is covered with a film of hydroxide which preserves it from further action of the air or the electrolyte. If, therefore, a piece of aluminum be made the anode in dilute $\mathrm{H}_{2} \mathrm{SO}_{4}$, the $\mathrm{SO}_{4}^{\prime \prime}$ ions are unable to pass through the film to the anode, and the Al $\cdots$ ions cannot pass from the anode into the solution. Hence there are

1 Part of a thesis presented to the Faculty of Sibley College for the degree of Electrical Engineer in June, I904.

${ }^{2}$ Phil. Mag. [6], 5, 30I (1903).

${ }^{3}$ Cf. Ostwald: Zeit. phys. Chem. 6, 71 (1890). 
no ions to carry electricity through the film, and no current can pass. A very small current does pass, and this may be due to A1 '. ions being formed at the anode, and $\mathrm{H}^{\cdot}$ ions of water passing at the same time through the film, and leaving $\mathrm{OH}^{\prime}$ ions, which form $\mathrm{Al}(\mathrm{OH})_{3}$ with the $\mathrm{Al} \cdots$ ions just formed. This aluminum hydroxide replaces that which may be removed by solution in the acid, and in this way the continuity of the film is maintained.

"If $\mathrm{Cl}^{\prime}, \mathrm{Br}^{\prime}$, or $\mathrm{NO}_{3}^{\prime}$ ions are present, they can migrate through the film, thus carrying electricity to the anode where they unite with Al $\cdots$ and form nentral salts, and this formation of salt behind the film will break it loose in spots and so enable the current to pass easily."

A rise of temperature is recognized as being fatal to the working of the aluminum rectifier when aqueous solutions are used. The temperature at the surface of the electrode is the important factor and not the mean temperature of the solution. These two are by no means the same. ${ }^{1}$ It is more rational to apply the cooling where it is needed, ${ }^{2}$ and it was therefore decided to make a series of tests on the behavior of water-cooled electrodes. The work was divided into two parts. In the first part measurements were made on the behavior of different electrolytes when using a direct current. The object of this was to determine the minimum leakage current at different voltages, since it is known that an alternating current always gives a higher leakage than does a direct current. In the second part of the work a number of efficiency runs were made with a single electrolyte.

\section{STUDY OF ELECTROLYTES}

\section{Description of Apparatus and Instruments}

. In order to study the action of various electrolytes, a series of runs were made to determine the voltage required to rupture the films; the.amount of leakage current and the point at which

1 Richarz and Ziegler, Wied. Ann. 63, 261 (1897).

2 Fischer, Zeit. Elektrochemie, 10, 543 (1904). 
it began to increase rapidly; the rise in temperature of the electrolyte during a run, and other points of a similar nature.

The electrolytes studied were disodium phosphate, sulphuric acid, and citric acid. Phosphoric acid, which acts like disodium phosphate, and which was used in the efficiency runs later, was not studied very fully, because of the similarity of action between an acid and its salts under these circumstances.

These substances were all used in succession in the same cell, and under as nearly similar conditions as could be obtained. The tank used was a small rectangular vessel, about $6 \times$ io $\times 6$ inches in size, with rather thick walls. Glass was used rather than another material because it allowed a clear view of the aluminum anode, so that all changes in the appearance of the film could be observed.

The aluminum anode was a seamless tube, stipplied to us very courteously by the Pittsburgh Reduction Company, and was coiled up into two complete turns, with the two ends extending out of the electrolyte. To the two free ends short lengths of rubber tubing were attached, so that a stream of water could be allowed to flow through the tube, serving to keep the tube and the surrounding electrolyte cool. In this manner the temperature could be kept fairly constant during a run.

By bending the tube into a coil, a much larger surface of aluminum was exposed to the electrolyte than would otherwise have been possible. This larger surface kept the leakage current density at a low value, and this also assisted in keeping the tube itself cool. The coils were made as small as possible, care being taken to avoid rupture. In bending the tubes, which had comparatively thin walls, they were first filled with sand, and the ends tightly corked. They were then coiled by hand around a smooth cylinder, the sand with which they were filled preventing their being crushed during the process. Care was taken to avoid cutting or damaging the surface, as it is difficult to get the film to form over a rough or broken surface.

The temperature was measured by*a thermometer suspended in the electrolyte, close to the aluminum, so as to get the temperature at the film as nearly as possible. 
The second electrode was formed of a lead plate, which had a large surface exposed to the electrolyte, so that it was easily able to collect all the current which might flow, without heating to any perceptible degree.

The tank was cleaned by washing first with concentrated nitric acid, and then with water. A weak solution of ammonium hydroxide was then poured in, and finally the tank was thoroughly washed out and rinsed in distilled water. The lead electrode was treated in the same way.

The aluminum tube was cleaned by immersing it in a very dilute solution of sodium hydroxide, and allowing it to remain only until minute bubbles were seen to form on the surface, when it was removed and thoroughly washed in distilled water.

When the apparatus was cleaned and ready to use, it was assembled by placing the lead plate in one end of the tank, and the coiled aluminum in the other. These were suspended so as to rest a short distance from the bottom, and were then secured in position. The electrodes were about five inches apart at their nearest parts.

Connections were made to a steady supply of cool water, and arrangements made to allow a constant stream to flow through the tube during the test.

The direct current in the mains was at a pressure of 500 volts, and as it was necessary to begin at a very low pressure and come up to the full potential by small increments, without sudden jumps, some method of adjusting the voltage was necessary. To do this a lan1p rheostat was used. Eighteen r6-c. p. lamps were connected in two sets of "nine each in parallel, each set of nine being in series. Cross connections were also made so that pressures of from o volt to 500 volts could be obtained in nine steps of about 50 volts each. As it was desired to use still smaller increments of pressure, the current after passing the first rheostat was led through a second in series. This second rheostat consisted of several $\mathrm{U}$-tubes connected in series to form a liquid resistance, each leg being fitted with an adjustable electrode.

By combining these two rheostats in series, it was possible 
to go from o volt to 500 volts in steps of about 5 volts each. The use of two lamps in parallel enabled about an ampere to be drawn without endangering the lamps. In some cases where more current was required, 32-c. p. lamps were used.

The direct current used was applied in such a manner that the aluminum was always the anode, and the lead the cathode.

An ammeter was used to measure the current, and a voltmeter placed so as to measure the pressure applied across the cell. The ammeter had been carefully calibrated and was quite accurate. It was provided with two scales, one reading from 0.0 to 0.5 ampere and the other from 0.00 to 0.01 ampere. By starting on the lower scale and then changing over to the higher one, it was possible to read small values of current very accurately.

The voltmeter had three scales-from o to $\mathrm{I}_{5}$, from 0 to I 50 , and from o to 600 volts respectively. It was also calibrated and found to be quite accurate.

As the voltmeter was connected inside the ammeter, a small current flowed through the latter all the time. This was 0.005 ampere, approximately, and was deducted from the ammeter readings before they were recorded.

In order to protect the sensitive ammeter from a sudden rush of current through it, it was put in shunt by a single-pole switch, which was closed except when readings were being taken.

\section{METHODS OF MAKING TESTS}

When all the apparatus was in order and all the electrical connections had been made, the switches were closed and the lowest value of pressure applied. At first the current rose to a considerable value, and then slowly died away until it became constant. These permanent values are the ones recorded in the result sheets.

The reason for the sudden flow of current at first is that the aluminum is clean, and has no surface film. As the current passes, a film of aluminum hydroxide is formed on the surface of the aluminum anode while hydrogen is set free at the cathode.

As the film grows thicker, it opposes more and more effec- 
tively the passage of current, until finally a point is reached where only a very small leakage current passes, just sufficient to retain the film. This leakage current gives the permanent values recorded.

Each time the voltage is raised, a similar operation occurs, the leakage current increasing slowly in value as the voltage rises

So long as the voltage is below a certain critical value, this increase is very gradual. After this critical point is reached, the current increases very rapidly with a small increase in pressure, and soon reaches a point where the film is ruptured. Sometimes after the critical point is reached, the current continues to increase without any increase in the pressure whatever.

The point of rupture is known as the break-down point. It varies widely, depending upon the electrolyte used, the temperature in the film, the state of the film, and other conditions.

The thickness of the film varies directly with the pressure, and the higher the pressure, the thicker the film. When the film is first formed it is so thin that interference colors are produced when light falls on it in the proper direction. As the pressure increases, these colors pass from one to another, running through the spectrum in covering a range of about I25 volts. This can be shown by placing a strip of aluminum in the tank, and then raising it up out of the electrolyte for each step up in pressure, when the colors will appear in their order in bands, the width of which varies with the distance the aluminum is raised each time. The colors are very faint on low pressures and more intense on the higher values. The lower the break-down pressure, the smaller the variation in pressures required to run through the spectrum. Thus it is easily seen that each particular pressure has a certain value of film thickness. When, therefore, we do not increase the pressure gradually, but throw it on all at once, we are quite likely to rupture some weak point in the film before the current has had time to build the film up to the proper thickness required for the new and higher pressure. This is true even after the film has been worked at the lower voltage for a considerable time, and has had time to become comparatively thick. 
After the film has once been formed, as this process of producing a film by applying to it increasing values of pressure is termed, the film is not so sensitive to changes and we can come up to the critical pressure by much longer steps than otherwise, though we cannot, in any case, apply the full pressure immediately without drawing excessive currents for an instant. If the film does not rupture, this current is only momentary.

This is not, however, the point of greatest importance, since we never run very near the critical point in using the electrolyte in a rectifier, as the leakage current is entirely too great. Still, it is of some importance in showing the behavior of the film under these higher pressures.

If we allow the current to flow when the pressure is above the critical point, we get something analogous to the disruptive discharge. Furious sparking takes place all over the tube, but more especially just at the surface line of the liquid. The tube is rapidly destroyed, holes being torn clear through it in a few moments. The action occurs much more readily with certain electrodes than with others.

Even though the tube may not be punctured, we can never form a good film over any spot where this distuptive sparking has taken place. Excessive current will flow before the pressure is near the critical value, and will flow at lower and lower pressures as the tube continues in use. The spot where a discharge has occurred is rough, as though the particles of the metal had been torn out of place. There is also some blackening caused, a hard, grayish substance somewhat resembling corundum being formed. This was noted by Cook. ${ }^{1}$

By moving the tube so that the damaged spot is out of contact with the electrolyte, the use of the tube may be continued. Wrapping insulating tape over the spot has no effect whatever.

The effect of sparking on the break-down pressure can be shown by a direct conparison of results obtained before and after such sparking.

${ }^{1}$ Phys. Rev. 18, 23 (1904). 


\begin{tabular}{c|c|c}
\hline & Volts & Ampere \\
\hline Before disruptive sparking & 238 & 0.18 \\
After disruptive sparking & 288 & 0.20 \\
& I80 & 0.25 \\
& I 40 & 0.30
\end{tabular}

The conditions were exactly similar in all four cases.

Several runs were made in which no cooling water was used. If the pressure was maintained all the time and the tube given no chance to cool off, the temperature of the electrolyte rose, especially when the runs were long, and the break-down occurred at a much earlier point. If the run was short, or the pressure was applied intermittently, the results obtained were much the same as in the cases where cooling water was used. These results will be discussed in the varions sets of runs, as they were made.

As soon as any considerable leakage current flows, the temperature of the electrolyte rises, as its resistance is considerable. This heating tends to lower the break-down point and to increase the leakage current, and is to be avoided when possible. The rise in temperature as the leakage current increases is quite clearly shown in some of the runs.

\section{Test of Di-sodium Phosphate}

The first electrolyte to be studied was di-sodium phosphate $\left(\mathrm{Na}_{2} \mathrm{HPO}_{4}\right)$. A saturated solution of the salt was used in the tank. The film was slowly formed, the pressure first applied being 5 volts. It was then worked up by equal increments of 5 volts each to 165 volts, and was then considered to be formed sufficiently to permit making a run.

At first nothing could be seen. Then, as the pressure increased, gas began to be given off at both electrodes, in quantities small at first but increasing with the pressure, until it was quite noticeable.

Run 1 .- This was begun at 38 volts and carried up by easy stages. Gas was given off in small quantities, increasing up to I 75 volts when, by watching the cell with the room darkened, minute sparks could be seen at intervals, here and there over the 
tube. This sparking gradually increased until the end of the run, when 242 volts were applied, and the run was stopped in order not to spoil the film.

RUN I

\begin{tabular}{|c|c|c|c|c|c|}
\hline Temp. & Volts & Amperes & Temp. & Volts & Amperes \\
\hline $15^{\circ}$ & 0 & 0.0 & $14^{\circ}$ & 174 & 0.038 \\
\hline I 5 & 38 & 0.0042 & I 4 & $178^{1}$ & 0.040 \\
\hline 15 & 54 & 0.0053 & 14. & I 88 & 0.057 \\
\hline I 5 & 65 & 0.0068 & 14 & 196 & 0.0735 \\
\hline I 5 & 75 & 0.0072 & 14 & 206 & 0.089 \\
\hline 14.75 & 83 & 0.0088 & I 4 & 209 & 0.092 \\
\hline 14.75 & 105 & 0.0128 & 14 & 2 I 2 & 0.095 \\
\hline 14.5 & I I 5 & 0.0144 & I 4 & 216 & O. 125 \\
\hline I 4.25 & 120 & 0.0147 & 14 & 224 & 0.143 \\
\hline 14.25 & I 30 & 0.020 & 14 & 230 & 0.170 \\
\hline 14.25 & 148 & $0.02 \mathrm{I}$ & 14 & 234 & 0.180 \\
\hline 14.25 & I 56 & 0.023 & 14 & $238^{2}$ & 0.190 \\
\hline I 4 & 160 & 0.028 & 14 & 242 & 0.250 \\
\hline I 4 & I 70 & 0.032 & & & \\
\hline
\end{tabular}

The current increased very gradually from zero up to about 200 volts, when it began to increase more and more rapidly as the pressure rose. As can be seen from the curve (Fig. I), the critical point occurs somewhere between 175 and 200 volts. The temperature fell during the first of the run, due to the cooling water being very cold, and then remained constant.

The amount of gas given off increased with the current, until at the end of the run the electrolyte was made to look slightly whitish, due to the number of gas bubbles contained in it.

Run 2.- The second run was begun at 48 volts and carried on by increasing the pressure more rapidly than in Run I. At

RUN 2

\begin{tabular}{c|c|c|c|c|c}
\hline Temp. & Volts & Amperes & Temp. & Volts & Amperes \\
\hline I2.0 & 48 & 0.0025 & I I.75 & 284 & 0.100 \\
I2.0 & I0O & 0.006 & I I.75 & 300 & 0.200 \\
I2.0 & I60 & 0.011 & I I.75 & 304 & 0.220 \\
I2.0 & I 76 & 0.015 & I 1.75 & 308 & 0.250 \\
I2.0 & 208 & 0.018 & I 2.0 & $320^{3}$ & 0.500 \\
I2.0 & $240^{1}$ & 0.020 & & &
\end{tabular}

1 Visible sparking began.

3 Film ruptured.

sparking badly. 
240 volts the first visible sparking appeared. The current increased very slowly up to this point. Somewhere between 240 and 284 volts the critical point was passed. As the pressure rose, the current and the sparking increased rapidly until at 320 volts disruptive sparking occurred at one point just at the surface of the liquid, and ended the run. The bad spot on the tube was moved up out of the electrolyte, and the next run then taken.

Run 3.-This was very much the same as Run 2. Visible sparking began at 264 volts, corresponding to a sudden increase in current. The current continued to increase and at 325 volts

\begin{tabular}{l|c|l|c|c|c}
\multicolumn{8}{c}{ RUN 3} \\
\hline \hline Temp. & Volts & Ampere & Temp. & Volts & Ampere \\
\hline II.5 & 80 & 0.00265 & $10.0^{\circ}$ & $264^{1}$ & 0.065 \\
II.0 & 140 & 0.00565 & 10.0 & 280 & 0.150 \\
IO.5 & 160 & 0.00625 & 9.5 & 288 & 0.200 \\
IO.25 & 180 & 0.0080 & 9.0 & 294 & 0.2 .70 \\
IO.0 & 200 & 0.010 & 9.0 & $325^{2}$ & Off scale
\end{tabular}

the film was again ruptured. The critical point seems to have been somewhere between 200 and 264 volts.

These three runs were all taken, using cooling water in the tube. In most cases the temperature in the cell fell. This was because the cooling water was very much colder than the electrolyte at the beginning of the run, and also to the fact that the runs were begun before the cell had reached its lower temperature limit.

Run 4.-This run was taken without using cooling water. The values of the current were much larger than those in the previous runs, and sparking began at 140 volts. The temperature of the electrolyte rose steadily. After reaching I60 volts the run was stopped and the cell allowed to cool down. When the temperature had fallen to what it had been at the start the run was resumed, and it was found that although the pressure had raised to 176 volts, the current had fallen to one-fourth of 


\begin{tabular}{|c|c|c|c|c|c|}
\hline Temp. & Volts & Ampere & Temp. & Volts & Ampere \\
\hline $15^{\circ}$ & 0 & 0.0 & I $7.0^{\circ}$ & 100 & 0.034 \\
\hline I 5 & I. 5 & 0.00265 & 17.5 & I ro & 0.055 \\
\hline I 5 & 27.5 & 0.0048 & 18.0 & $140^{1}$ & 0.080 \\
\hline I 5 & 40.0 & 0.010 & 18.7 & 160 & O.IO \\
\hline I 5.2 & $5^{\circ}$ & 0.013 & - & $-^{2}$ & - \\
\hline I 5.6 & $5^{2}$ & 0.015 & I 5 & I 76 & 0.025 \\
\hline 16.0 & 55 & 0.017 & I 5.5 & 232 & 0.04 \\
\hline I6.25 & 70 & 0.025 & 16.0 & 252 & $0.06_{5}$ \\
\hline I 6.5 & 75 & $0.025 \mathrm{I}$ & I $6 . \mathrm{I}$ & $292^{8}$ & 0.250 \\
\hline 16.7 & 85 & 0.029 & & & \\
\hline
\end{tabular}

its value at $\mathrm{I} 60$ volts. Both current and temperature rapidly rose, the film being ruptured at 292 volts.

From these runs it seems that where cooling water is used it should be possible to work without difficulty up to 220 volts, after the film has been properly formed. The results of these runs are shown graphically in Fig. $x$.

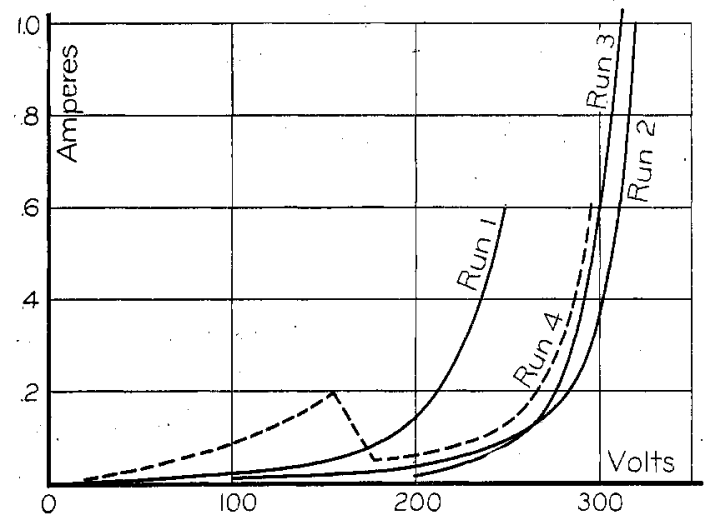

Fig. I

\section{TEST OF SULPHURIC ACID}

After completing the test of the di-sodium phosphate solution, the apparatus was taken apart and cleaned before beginning the runs. The old aluminum tube was discarded, as the

\footnotetext{
I Sparking. $\quad{ }^{2}$ Stopped to let cell cool. $\quad{ }^{3}$ Film ruptured.
} 
disruptive sparking to which it had been exposed had practically destroyed its further usefulness, and a new tube was substituted. This tube was as nearly like the old one as was possible, both in size and form.

The new electrolyte was sulphuric acid. This was as pure as possible, being known as storage battery acid, and had a specific gravity of I.2. While this density does not correspond to the maximum conductivity, yet it is quite near to it and answers very well for the purposes of the test. Electrical connections and the arrangement of the cell and apparatus remained as in the previous test.

Run 5.-This run was begun applying a pressure of 5 volts across the cell. The pressure was then increased by easy stages up to IO3 volts, when the film broke down, though it was not destroyed in spots, as in the previous case. Instead there seemed to be a general giving way of the film all, over the tube, so that the current was able to pass without doing much damage.

\begin{tabular}{|c|c|c|c|c|c|}
\hline Temp. & Volts & Ampere & Temp. & Volts & Amperes \\
\hline I $3.5^{\circ}$ & 5 & 0.0035 & I $2.25^{\circ}$ & 62 & $0.215^{\circ}$ \\
\hline I 3.25 & Io & 0.0045 & 12.25 & 67 & 0.300 \\
\hline I 3.0 & I 5 & 0.0074 & I 2.25 & 73.5 & 0.400 \\
\hline I 2.75 & 25 & 0.0140 & 12.0 & 76.0 & 0.950 \\
\hline I 2.75 & 40 & 0.0650 & I 2.0 & $103.0^{1}$ & 1.350 \\
\hline I 2.5 & 48 & O. IIO & & & \\
\hline
\end{tabular}

The critical region is not so clearly defined as in the previous cases. The leakage current rises rather rapidly after passing about 40 volts, and while the film is not actually broken down at IO3 volts, it permits of so great a leakage current as to render the operation of the apparatus as a rectifier impossible.

Run 6.-This run was the same in all particulars except that no cooling water was used. The values of the current lie below those obtained in Run 5, partly because of the fact that the film had already been formed by the previous run, and partly because of the lower temperature obtained in the tank in that run.

\footnotetext{
1 Film ruptured.
} 
RUN 6

\begin{tabular}{|c|c|c|c|c|c|}
\hline Temp. & Volts & Ampere & Temp. & Volts & Ampere \\
\hline $9.5^{\circ}$ & 5 & 0.005 & $10.0^{\circ}$ & 40 & 0.025 \\
\hline 9.5 & IO & 0.010 & 10.0 & 53.5 & 0.130 \\
\hline 9.5 & 20 & 0.012 & IO. I & 64 & O. I $55^{\circ}$ \\
\hline 9.5 & 26 & 0.015 & 10.2 & 70 & 0.250 \\
\hline 9.5 & 30 & 0.018 & 10.5 & $78^{1}$ & $0.85^{\circ}$ \\
\hline
\end{tabular}

As-before, the current rises rapidly after about 40 volts has been applied, but the curve bends upward much more sharply, showing that the critical point lies somewhere between 65 and 75 volts. The run was stopped before the film was damaged.

There was no noticeable sparking in either of these runs, probably because the pressure was not sufficiently high. Quantities of gas were given off, however, increasing as the current rose, so that toward the end of the run the electrolyte was so filled with bubbles of gas as to be whitish in color and almost opaque.

While no test was made of the gas given off, it seems probable that it was mostly hydrogen and oxygen together with a little sulphur dioxide or other impurities which gave it a penetrating odor and made it very disagreeable to breathe, as it irritated the air passages and produced coughing and soreness.

\section{Test of Citric Acid}

It was now decided to try some organic acid as the electrolyte, in order to find out the possibilities in that direction. Accordingly, citric acid was chosen as being convenient, cheap, and readily obtainable.

The apparatus was cleaned and arranged as before, and as the tube had not been damaged, it was decided to use the same one over again. Before putting in the new electrolyte, how. ever, it was thoroughly scrubbed in running water to free it from all traces of sulphuric acid. While it is not advisable to use the same tube in more than one solution, it was done here to economize on material and time. The electrolyte was a solution of

1 Film breaking. 
citric acid in water, Ioo grams of the crystallized acid being dissolved in I. 5 liters of water.

-The effect of the use of the tube in another solution is clearly shown in Runs 7, 8, 9, and Io. As the impurities were eliminated and a new film formed, we can reach successively higher and higher pressures without increasing the current leakage.

In making these runs the pressure was run up until the critical point was reached, when the pressure was taken off for a few moments and then applied again at a very much lower value. On running up a second time it was found possible to reach a very much higher pressure than before, without damaging the film. This process is beautifully shown by the curves in Fig. 2. The last curve, No. IO, seemed to represent nearly standard results with this tube.

Run 7.-In this run the pressure first applied was Io volts, and it was then run up by small increments to $5_{5} 6$ volts, where

RUN 7

\begin{tabular}{|c|c|c|c|c|c|}
\hline Temp. & Volts & Ampere & Temp. & Volts & Ampere \\
\hline $14.0^{\circ}$ & IO & 0.0016 & $12.50^{\circ}$ & 105 & 0.022 \\
\hline 14.0 & 20 & 0.0025 & I 2.25 & I IO & 0.030 \\
\hline 14.0 & 40 & 0.0046 & I 2.20 & I 20 & 0.077 \\
\hline 13.5 & 60 & 0.0073 & I 2.0 & I 35 & 0.210 \\
\hline I 3.0 & 80 & 0.0120 & II. 5 & I $5^{\circ}$ & 0.300 \\
\hline I 2.75 & 93 & 0.0180 & I I. 5 & $156^{1}$ & 0.320 \\
\hline
\end{tabular}

the run was stopped. The current rose very gradually until roo volts was reached, and then increased very rapidly until the end of the run.

Run 8.-After the end of Run 7 the cell was allowed to rest for a few moments, and the pressure was again applied, starting this time at 56 volts and running up to IO2 volts, when the run was stopped. The current began at a very low value and in-

I Film weakening. 
RuN 8

\begin{tabular}{|c|c|c|c|c|c|}
\hline Temp. & Volts & Ampere & Temp. & Volts & Ampere \\
\hline I I. $0^{\circ}$ & 56 & 0.002 & $10.75^{\circ}$ & I 66 & 0.190 \\
\hline 10.75 & 108 & 0.005 & 10.50 & I $80^{I}$ & 0.290 \\
\hline 10.75 & 140 & 0.075 & 10.50 & 202 & 0.340 \\
\hline 10.75 & 150 & .0.170 & & & \\
\hline
\end{tabular}

creased slowly up to about 40 volts, then increasing rapidly to the end of the run.

Run 9.-The cell was given a few moments to recover; the pressure was again applied, starting at 68 volts and running up to $4 \mathrm{I} 2$ volts. The current increased very slowly at first, giving RUN 9

\begin{tabular}{|c|c|c|c|c|c|}
\hline Temp. & Volts & Ampere & Temp. & Volts & Amperes \\
\hline $10^{\circ}$ & 68 & 0.002 & IO. $1^{\circ}$ & $3^{10}$ & 0.80 \\
\hline IO & I 32 & 0.005 & I0.25 & $400^{2}$ & 2.00 \\
\hline IO & 200 & 0.009 & 10.4 & 408 & 2.10 \\
\hline 10 & 240 & 0.080 & 10.5 & 4 I 2 & 2.20 \\
\hline 10 & 260 & 0.260 & & & \\
\hline
\end{tabular}

a critical value of about 225 volts. From there it increased quite rapidly until 3 IO volts was reached. The film then broke down, the value of current obtained at 4I2 volts being so large as to show this clearly.

Run 10.-After the cell had been restored to normal conditions a pressure of 60 volts was applied and another run started. The pressure was run up to 424 volts, when the film was seen to be breaking and the run was stopped.

\begin{tabular}{l|l|l|l|l|l}
\multicolumn{7}{c}{ RUN IO } \\
\hline Temp. & Volts & Ampere & Temp. & Volts & Ampere \\
\hline I3.25 & 60 & 0.002 & I 2.0 & 318 & 0.125 \\
I3.25 & 1 I 2 & 0.003 & I I.5 & 352 & 0.630 \\
I3.0 & I 40 & 0.005 & I I.5 & 356 & 0.650 \\
I3.0 & 208 & 0.0065 & I I.25 & 360 & 0.670 \\
I2.5. & 264 & 0.010 & I I.0 & 364 & 0.700 \\
I 2.0 & 288 & 0.025 & I I.6 & $424^{2}$ & 1.80
\end{tabular}

${ }^{1}$ Film weakening.

${ }^{2}$ Film breaking. 
The current increased slowly at first, giving a critical point of from 300 to 325 volts. A rapid increase up to 364 volts followed where the film was still good. The next step in pressure produced such a large increase in current that the film was known to be giving way, and the run was at once stopped.

The data for Runs 7-Io are represented graphically in Fig. 2.

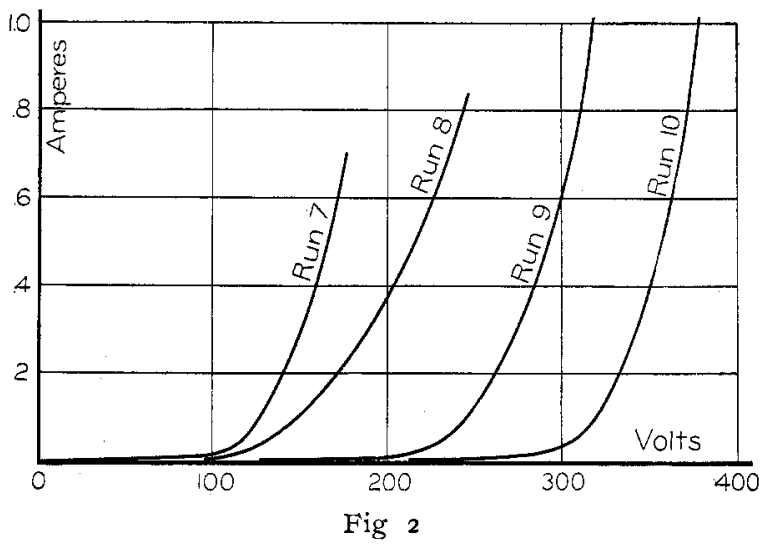

Test of Dilute Solution of Citric Acid

After completing these runs it was thought desirable to see if the concentration of the solution made any difference in the action. The electrolyte was diluted to one-tenth of its former strength, and a new aluminum tube was prepared and placed in position. Everything else was as in previous runs.

Run II. - The run was begun at a very low pressure, and carried up to the highest voltage obtainable from the line (508 volts). The current increased very gradually, and the form of the curve shows that the critical pressure lies somewhere at about 500 volts. It was impossible to determine the breaking pressure for the reasons stated above.

RUN II

\begin{tabular}{|c|c|c|c|c|c|}
\hline Temp. & Volts & Ampere & Temp. & Volts & Ampere \\
\hline $10^{\circ}$ & 80 & 0.005 & I0. $25^{\circ}$ & 332 & 0.0450 \\
\hline IO & $\mathrm{IO}_{4}$ & 0.0055 & IO. 0 & 420 & O.IIO \\
\hline Io & 160 & 0.010 & 10.0 & 492 & 0.260 \\
\hline IO & I 96 & 0.0110 & 10.0 & 500 & 0.290 \\
\hline IO & 234 & 0.0125 & 10.0 & $508^{1}$ & 0.320 \\
\hline IO & 284 & $0.015^{\circ}$ & & & \\
\hline
\end{tabular}

1 Film still good. 
In the first four runs there was no visible sparking, although some sparking occurred, as the tube was slightly blackened and - pitted near the surface line of the liquid. Gas was given off much as in the runs taken with sulphuric acid, although the amount was not quite so great.

In the run with the dilute acid there was no sparking, and little gas was given off, as the pressure at no time rose above the critical value.

\section{RESULTS OF TESTS OF ELECTROLYTE}

As a final step a representative run was selected from each of the four sets of runs, and these were all plotted on one sheet to the same scale (Fig. 3). The ones selected were:

$$
\begin{aligned}
& \text { From Set I-Run } 2 \text {. } \\
& \text { " "2-" } 5 \text {. } \\
& \text { " "3-" IO. } \\
& \text { " "4 " " II. }
\end{aligned}
$$

The runs selected were all ones in which cooling water had been used, so that it was possible to compare the action of the film in different electrolytes under similar conditions.

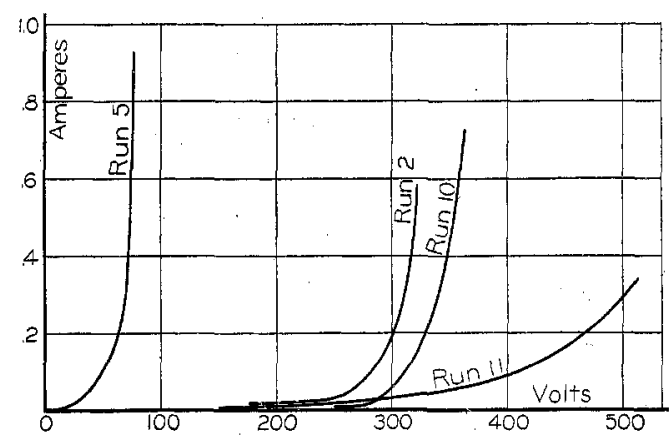

Fig. 3.

As can be seen from the curves, the sulphuric acid has the lowest critical value. If it is desired to use it as the electrolyte in a cell, the pressure should not exceed 55 volts; if excessive leakage is to be avoided. The di-sodium phosphate comes next, but has a very much higher critical value. It should permit the pressure to be worked up to 220 volts without allowing any onsiderable leakage. The critical value of the concentrated 
citric acid lies somewhere about 300 volts. It can be seen from the curves that it follows the di-sodium phosphate quite closely. The dilute citric acid has the highest critical value of all, as the current is just beginning to increase rapidly at that point. It has, however, a more steady rise than the others, and to correspond to the others in the amount of leakage current allowed, it should not be worked above 325 volts.

While these curves show which electrolyte has the highest critical value and breaking point, they do not show which ones will work the best in a rectifier, as other considerations then enter in. As it is, however, they indicate which ones will probably give the best results, and thus are quite useful as far as they go.

\section{THE ALUMINIUM RECTIFIER Choice of Electrolyte.}

Citric acid solutions are of no value for a rectifier because the conductivity is too low. It is also a question whether any organic acid would withstand oxidation for any length of time. Sulphuric acid is out of the question because it attacks the film too readily. This leaves phosphate or phosphoric acid solutions as the only ones available. Sodium phosphate was rejected because of the possible disadvantage of a formation of caustic soda at the cathode. While admirable results have been obtained with ammonium phosphate solutions, it was thought best to start with a simpler electrolyte, with phosphoric acid.

The electrolyte accordingly was phosphoric acid diluted with water to that concentration which produced maximum conductivity. This was a 45 percent solution of the syrupy acid in water. The solution would have much the same critical and breaking points as the di-sodium phosphate. As the critical value with this solution lies at about 300 volts, no trouble was to be expected on a I Io-volt circuit.

The conductivity of sulphuric acid is very much greater than any of the other electrolytes used, but the fact that it must not be worked at above 55 volts prevented its use in this case, although a run was made later on, using it in combination with phosphoric acid. 


\section{DESCRIPTION OF THE RECTIFIER}

The rectifier consisted of four cells so arranged as to secure all the current. Each cell contained one aluminum electrode and a pair of graphite or lead electrodes. The cells themselves were made of beakers, as these were convenient in form and size and well adapted to the purpose.

The aluminum electrodes each consisted of a piece of aluminum tubing about nine inches long and three-eighths of an inch in diameter, bent into the form of a $U$, so that they could be placed inside of the beakers. The length of tube in the electrolyte was the same in all cases, approximately six and threeeighths inches, and the area of aluminum exposed to the electrolyte was, therefore, 2.82 square inches per cell. It is necessary that the aluminum should have very nearly the same area exposed to the electrolyte in each cell, as otherwise there would be a greater leakage than there is when the cells are evenly balanced. Care must be taken to avoid cutting or marring the surface of the tube, owing to the difficulty of forming a film over a roughened spot.

The electrodes should be placed as close together as possible without forming short circuits, in order to reduce the resistance of the cell to as low a figure as possible, because such resistance in the cell cuts down the available voltage very seriously on heavy loads. In these cells the electrodes were approximately three-eighths of an inch apart at the bottom, and one-half an inch at the top.

The aluminum electrodes were connected by rubber tubing so that cooling water conld flow in at one end of the system and out at the other, keeping the tubes and electrolyte cool. The temperature was measured by two thermometers, one in the cell through which the water entered and the other in the cell at which it left. Under ordinary circumstances these read the same, and only one reading was recorded.

The electrical connections were made as shown in Fig. 4. The alternating current from the mains, 60 cycles and I Io volts, was led through an ammeter and a wattmeter to the rectifier. Here each side of the circuit was divided into two branches, one of which went to an aluminum electrode, and the other to a graphite or lead electrode. On the other side two aluminum 
electrodes were connected together to form one side of the direct current circuit, and two graphite or lead electrodes were joined to form the other side. The current, after passing

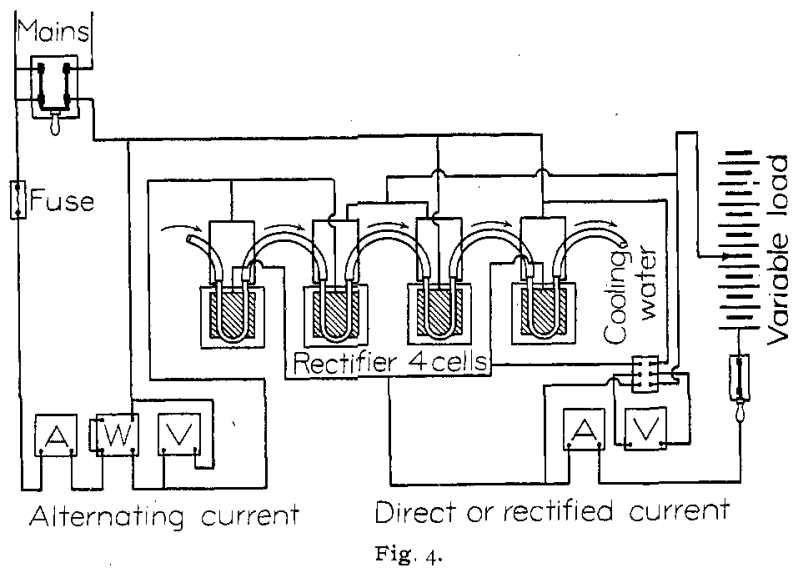

throngh the ammeter, was led to the load. It was regulated by the amount of resistance in the direct current side. When this was on open circuit, only the leakage current flowed, and under these circumstances it was comparatively small. Unfortunately, this leakage current increased with the load, though not in direct proportion to the current flowing. With no load, this leakage current amounted to between 0.3 and 0.5 ampere.

A voltmeter placed across the mains measured the pressure of the incoming alternating current. It was arranged with a double throw switch so that the drop in voltage across a cell could be obtained, and the resistance of the cell thus obtained.

Two ammeters were used on the alternating current side, one in reading from 0.0 to 2.0 amperes, and the other from 0.0 to 25.0 amperes. These were accurately calibrated with the Thomson balance in the laboratory. The direct current ammeter was supplied with a shunt, so that it read from o to 'Io amperes. This was also calibrated on the Thomson balance.

The A. C. voltmeter read to I 30 volts, and the D. C. to I 50 volts on two scales. These were carefully calibrated by a Weston voltmeter reading to 0.05 volt, belonging to the Department of Physics. The wattmeter was calibrated by means 
of the ammeter and voltmeter, incandescent lamps being used as a load.

It is claimed that a direct current wattmeter should be used in the direct current side, as, owing to the distorted wave form, the ammeter readings are likely to be in error. Unfortunately, one of these was not available for the test. The anmeter can, however, be checked by inserting a copper voltameter in series with it. This was done here, and the ammeter was found to be approximately correct. In case the needle was swinging at the time when a reading was to be taken, the limits of the swing were observed and the average taken as expressing as nearly as might be the correct reading.

Each cell when assembled was "formed" by applying a direct current to it, with the aluminum as the anode. The pressure was run up in one or two steps to a pressure corresponding to the alternating current pressure which the cell was to rectify. Had an "auto" transformer been available, the aluminum could have been "formed" direct by applying a low value of alternating pressure at first, and gradually raising it to the working pressure. The aluminum having been formed and the cells arranged and all, connections made, the current was turned on and a run started.

The current flowing through the rectifier was small at first and was increased step by step until the capacity of the cells was reached. During the run, readings of all the electrical instruments, as well as the temperature of the electrolyte near the aluminum tubes, were taken simultaneously every five minutes.

Each value of current was maintained for half an hour by adjusting the resistance in the direct current circuit. After changing to the next succeeding value of current, some time was allowed to pass before readings were taken in order to permit everything to settle to a state of equilibrium under the new conditions.

Each run was once repeated under exactly similar conditions, as a check on the results. The second run was usually made with a fewer number of current values to cover the range, as it was made merely as a check to the first, and the form of the curves was sure to be closely the same. 
When the rectifier was in operation, gas was given off continuously in quantities sufficient to make the electrolyte almost opaque. A little water was added every day or two to compensate for that lost as gas. Otherwise the electrolyte remained unchanged, as there was no perceptible electrolytic action on the phosphoric acid. The quantity of gas given off appeared to vary directly as the current though no quantitative measurements were made.

The current taken by the rectifier was not very steady, partly owing to the variations in voltage and to changes in the cell. At times the current would run up to half again its steady valiue, when there would be a sharp crackling in the cell, and the current would then subside. This action occurred especially toward the end of a run when the cell was carrying a comparatively heavy current, and was sometimes so frequent as to render it very difficult to get satisfactory electrical readings.

After the end of a run, if the circuit was opened suddenly or the load removed so that the cell was relieved at once, a sharp crackling could be heard in the cells for a moment after the current had ceased. These crackling noises are probably due to some molecular change going on in the aluminum or in the electrolyte, or both, as the tension tunder which they had been working was suddenly removed.

It was found advisable to remove the aluminum tubes from the electrolyte when not in use, for there seemed to be some dissolving action in the cell, or at the surface line of the electrolyte, so that the aluminum drew an excess of current for a few moments after the circuit was closed, unless this was done. This trouble can be obviated by starting through a resistance. A small inductive resistance in the A. C. side answers quite well, as it has to carry a current for a short time only. This is advisable even when the tubes are removed from the electrolyte. In case the tubes are left in, it sometimes requires quite a little time for the excess current to subside.

The current drawn is not at unity power factor, but leads considerably. Thus the wattmeter reading is always less than the product of the volts and amperes. As the output, however, 
is in direct current, this power factor is not of so much importance. The power factor varies directly as the current, and approaches unity as the current approaches the capacity of the cell.

The direct current voltage obtained when the direct current end was on open circuit was much higher than when any load, however small, was put on the rectifier. A short table of results shows this clearly:

\begin{tabular}{c|c|c|c}
\hline \hline A. C. Voltmeter & A. C. Ammeter & A. C. Wattmeter & D. C. Volts \\
\hline I03.0 & 0.50 & 30 & 70 \\
I07.5 & 0.44 & 20 & 76 \\
I06.0 & 0.32 & 10 & 74 \\
106.5 & 0.36 & 15 & 73 \\
I 10.0 & 0.30 & IO & 73
\end{tabular}

The highest voltage obtained under load seldom exceeded 50 volts, the applied pressure being the same.

\section{COMPUTATION OF RESULTS}

The results were computed from the readings taken, in the manner shown below. The electrical quantities observed were alternating current amperes, volts, watts, and direct current volts and amperes. The direct current amperes were obtained as the product of the direct current volts and amperes. The power factor was obtained from the alternating current values by substituting in the equation

$$
\begin{aligned}
\mathrm{ECP}_{f} & =\mathrm{W} \\
\mathrm{P}_{f} & =\mathrm{W} /(\mathrm{EC}),
\end{aligned}
$$

in which $\mathrm{E}=$ voltage, $\mathrm{C}=$ current, $\mathrm{P}_{f}=$ power factor, and $\mathrm{W}=$ watts.

The current efficiency was obtained by dividing the direct current output by the alternating current input, and the same applies to energy efficiency as well.

The voltage efficiency was computed in a similar manner for each reading, but is not the true efficiency, which was found as follows: The effective value of the alternating current electromotive force is divided into the direct current voltage. The effective e. m. f. $=$ voltmeter reading $\times \sqrt{2 \times} 2 / \pi$. 
The average of the alternating current voltages during half an hour was found and reduced to its effective value. The average of the direct current voltmeter reading for the same period of the run, was also found. This latter, then, divided by the effective e. $m$. f. gives the true voltage efficiency, as recorded in the average of results, and shown in the voltage efficiency curves.

\section{Efficiency Run I.}

In the first efficiency run the arrangement of cells and apparatus previously described was used. One electrode was of aluminum, of course, and the other was formed by two strips of Acheson graphite placed one on each side of the aluminum and electrically connected so as to form one electrode. The electrolyte used was a 45 percent solution of phosphoric acid.

The run began with 0.25 ampere of current flowing on the direct current side. The current was raised by steps up to over 3 amperes on the direct current side, and as the readings were very irregulat and the temperature of the electrolyte had begun to rise, the run was discontinued.

The readings obtained are recorded (corrected) on the data sheet under Table $\mathrm{I}, \mathrm{P}_{f}$ standing for power factor, $\mathrm{V}$. $\mathrm{E}$. for voltage efficiency, C. E. for current efficiency, and E. E. for energy efficiency. The values under "Average" are the mean of the set except for the voltage efficiency where the mean true efficiency is put down.

TABLE I.

\begin{tabular}{|c|c|c|c|c|c|c|c|c|c|c|}
\hline \multirow[b]{2}{*}{ Temp. } & \multicolumn{3}{|c|}{ Alternating } & \multicolumn{3}{|c|}{ Direct } & \multicolumn{4}{|c|}{ Percent efficiency } \\
\hline & Volts & Amp. & Watts & Volts & Amp. & Watts & $P_{f}$ & V. E. & C. E. & E. E. \\
\hline $12.0^{\circ}$ & 102.0 & 0.62 & 25.0 & 35.0 & 0.26 & 9.10 & 39.5 & 34.3 & 42.0 & 35.4 \\
\hline I 2.0 & 103.5 & 0.72 & 26.3 & 32.5 & 0.28 & 9. I I & 35.4 & 31.4 & 38.9 & 34.7 \\
\hline I 2.0 & 105.5 & 0.70 & 26.0 & 34.0 & 0.26 & 8.85 & 36.2 & 32.3 & 37.2 & 34.1 \\
\hline 12.0 & 109.5 & 0.70 & $27 \circ$ & 36.0 & 0.29 & 10.45 & $35 \cdot 3$ & 32.9 & $4 \mathrm{I} .5$ & $3^{8} .7$ \\
\hline I I. 7 & 108.0 & 0.78 & 27.0 & 34.5 & 0.28 & $9 \cdot 7$ & 32.1 & 31.9 & 35.9 & 36.1 \\
\hline I I. 5 & 108.5 & 0.70 & 270 & 35.0 & 0.28 & 9.8 & 35.5 & 32.3 & 40.0 & 36.3 \\
\hline I I. 5 & 108.5 & 0.68 & 25.0 & 34.0 & 0.27 & 9.18 & $33 \cdot 9$ & 31.3 & 39.7 & 36.7 \\
\hline Aver & & & & & & & & $36 . x$ & & 36.3 \\
\hline
\end{tabular}


TABLE I.-(Continued).

\begin{tabular}{|c|c|c|c|c|c|c|c|c|c|c|}
\hline \multirow[b]{2}{*}{ Temp. } & \multicolumn{3}{|c|}{ Alternating } & \multicolumn{3}{|c|}{ Direct } & \multicolumn{4}{|c|}{ Percent efficiency } \\
\hline & Volts & Amp. & Watts & Volts & Amp. & Watts & $\mathrm{P}_{f}$ & V. E. & C. E. & E. E. \\
\hline I I. $7^{\circ}$ & 105.5 & 0.64 & 30 & 38.0 & 0.25 & 9.50 & 44.5 & 36.0 & $39 . I$ & 31.7 \\
\hline I I. 5 & 109.0 & 0.59 & $2 \mathrm{I}$ & $4 I .5$ & 0.27 & I I.2O & 32.7 & 38.0 & 45.8 & 53.4 \\
\hline I I. 5 & 107.5 & 0.59 & 25 & 39.0 & 0.25 & 9.75 & 38.4 & 36.3 & 42.4 & 39.9 \\
\hline I I. 2 & 108.5 & 0.60 & 25 & 41.0 & 0.26 & 10.65 & $3^{8.4}$ & 37.8 & 43.3 & 42.6 \\
\hline I I, 2 & 108.5 & 0.59 & 20 & 43.0 & 0.27 & II.6I & 31.4 & 39.7 & 45.8 & 58.1 \\
\hline I I. 2 & $\operatorname{IOg} .5$ & 0.58 & 23 & 42.5 & 0.25 & 10.62 & 36.3 & 38.8 & $43 . I$ & 46.2 \\
\hline I 1.2 & IIO 5 & $0.6 \mathrm{I}$ & 22 & 43.0 & 0.26 & II:I 8 & 32.7 & 38.9 & 42.7 & 50.8 \\
\hline \multicolumn{2}{|c|}{ Average, } & 0.60 & & & & & 36.5 & 42.3 & 43.2 & 46.1 \\
\hline I I. 5 & I IO.O & 0.85 & $5^{\circ}$ & 31.0 & 0.55 & 17.10 & 53.5 & 28.2 & 64.7 & 33.2 \\
\hline I 2.0 & 108.5 & 0.98 & 82 & 31.0 & 0.55 & 17.10 & 77.2 & 28.5 & 55.2 & 20.9 \\
\hline 12.0 & I 10.5 & 0.92 & 60 & 33.0 & 0.55 & 18.30 & 59.0 & 29.9 & 159.8 & 30.5 \\
\hline 12.0 & 108.5 & 0.97 & 60 & 32.0 & 0.56 & I 7.92 & 57.0 & 29.6 & 57.8 & 29.9 \\
\hline 12.0 & 110.5 & 0.92 & 55 & 34.0 & 0.57 & 19.38 & 54.0 & 31.7 & 62.0 & 35.3 \\
\hline I 2.0 & 108.5 & 0.97 & 60 & 34.0 & 0.60 & 21.00 & 59.0 & 31.3 & 61.8 & $35 . \mathrm{I}$ \\
\hline 12.0 & 1095 & 0.92 & 55 & 32.0 & 0.57 & 18.21 & 54.5 & 29.3 & 62.0 & 33.2 \\
\hline \multicolumn{2}{|c|}{ Average, } & 0.933 & & & & & $59 . \mathrm{I}$ & 33.2 & 60.47 & $3 \mathrm{I} . \mathrm{I}$ \\
\hline 12.0 & IIO.O & 1.05 & 82 & 33.0 & 0.85 & 28.62 & 71.0 & 30.0 & 81.0 & 34.4 \\
\hline 12.0 & 108.0 & 1.08 & 80 & $31.0^{1}$ & 0.82 & $25 \cdot 4$ & $7^{0.4}$ & 28.7 & 75.9 & $3 \mathrm{I} .7$ \\
\hline I I. 7 & 108.5 & 1.08 & 75 & 33.0 & 0.85 & 2802 & 64.0 & 30.5 & 78.7 & $37 \cdot 7$ \\
\hline I 2.0 & 105.5 & I.08 & 80 & 30.0 & 0.82 & 24.6 & 70.2 & 28.4 & 75.9 & 30.7 \\
\hline I 2.0 & 107.5 & 0.98 & 65 & 34.0 & 0.82 & 27.85 & 61.7 & 31.7 & 83.7 & 42.9 \\
\hline I 2.0 & 107.0 & 0.95 & 70 & 32.5 & 0.85 & 27.6 & 68.8 & 30.4 & 89.5 & $39 \cdot 4$ \\
\hline I 2.0 & 107.5 & 1.03 & 70 & 33.0 & 0.80 & 26.4 & 68.2 & 30.7 & 74.4 & $37 \cdot 7$ \\
\hline \multicolumn{2}{|c|}{ Average, } & I.035 & & & & & 67.7 & 33.8 & 79.87 & 36.35 \\
\hline 12.0 & 106.5 & I. 45 & I I 5 & $29 \cdot 5$ & I. I 5 & 33.9 & 97.2 & 27.7 & $79 \cdot 3$ & 29.5 \\
\hline 12.0 & 107.5 & I. 45 & I I 5 & 32.0 & I.I 8 & 37.8 & 96.5 & 29.7 & $8 \mathrm{I} .4$ & $32 . I$ \\
\hline 12.0 & 104.0 & 1.35 & 100 & 29.0 & I.I 8 & 34.2 & 71.3 & 27.9 & 87.5 & 34.2 \\
\hline 12.0 & 104.0 & $\mathrm{I} .35$ & 105 & 29.5 & I. 20 & 35.4 & 74.9 & 28.3 & 88.9 & 33.7 \\
\hline I 2.0 & 106.5 & I. 50 & 120 & 3 r.o & I. 25 & 38.8 & 75.2 & 29.1 & 83.3 & 32.3 \\
\hline I 2.0 & 105.5 & 1.45 & I I 5 & 30.5 & 1.20 & 36.6 & 75.2 & 28.7 & 82.8 & $3 I .8$ \\
\hline 12.0 & 106.5 & 1.50 & I 25 & 30.5 & 1.25 & 38.2 & 78.3 & 28.7 & 83.3 & 30.5 \\
\hline \multicolumn{2}{|c|}{ Average, } & 1.435 & & & & & 81.2 & 31.9 & 83.8 & 32.01 \\
\hline
\end{tabular}


TABLE I.-(Continued).

\begin{tabular}{|c|c|c|c|c|c|c|c|c|c|c|}
\hline \multirow[b]{2}{*}{ Temp. } & \multicolumn{3}{|c|}{ Alternating } & \multicolumn{3}{|c|}{ Direct } & \multicolumn{4}{|c|}{ Percent efficiency } \\
\hline & Volts & Anp. & Watts & Volts & Amp. & Watts & $\mathrm{P}_{f}$ & V. E. & C. E. & E. E. \\
\hline I $2.0^{\circ}$ & IO4.5 & 2.2 & I90 & 26.0 & I. 6.5 & 42.9 & 82.5 & 24.9 & 78.6 & 22.6 \\
\hline $\mathrm{I} 2.2$ & 105.5 & 2.4 & I 75 & 27.0 & 1.70 & & 69.0 & 25.6 & 70.8 & 26.3 \\
\hline I 2.5 & 105.5 & 2.3 & I75 & & 1.70 & & 72.2 & 25.6 & 73.9 & 26.3 \\
\hline I 3.0 & 103.5 & 2.4 & 200 & 26.5 & 1.82 & 48.2 & 80.6 & 25.6 & 75.8 & $24 . \mathrm{I}$ \\
\hline 13.0 & 107.0 & 2.5 & I90 & 29.0 & 1.80 & 52.2 & 71.0 & 27.1 & 72.0 & 27.5 \\
\hline 13.0 & 109.0 & 2.4 & I 85 & 31.0 & 1.70 & 52.7 & 70.7 & 28.4 & 70.8 & 28.5 \\
\hline I 3.0 & I08.0 & 2.5 & I 80 & 30.5 & 1.80 & 54.9 & 66.7 & 28.2 & 72.1 & 30.5 \\
\hline \multicolumn{2}{|c|}{ Average, } & 2.385 & & & & & 73.2 & 29.5 & $73 \cdot 42$ & 26.54 \\
\hline I 3.0 & 109.5 & $3 \cdot 4$ & 305 & 29.0 & 2.55 & 74.0 & 82.0 & 26.5 & 75.0 & $24 \cdot 3$ \\
\hline I 3.5 & 104.0 & 3.4 & 305 & 26.0 & 2.50 & 65.0 & 86.5 & 25.0 & 73.6 & 20.9 \\
\hline I 3.5 & 1.04 .0 & 3.2 & 305 & 26.0 & 2.60 & 67.6 & 91.7 & 25.0 & $8 \mathrm{I} . \mathrm{I}$ & $2 \mathrm{I} .9$ \\
\hline $13 \cdot 3$ & 108.5 & 3.5 & 295 & 29.0 & 2.45 & $7 \mathrm{I} . \mathrm{I}$ & 77.8 & 25.8 & 70.1 & 20.3 \\
\hline I $3 \cdot 3$ & $\mathrm{I} O 3.5$ & 3.2 & 275 & 25.0 & 2.40 & 60.0 & 83.0 & 24. I & 75.0 & 21.9 \\
\hline I 3.3 & 104.5 & 3.2 & 275 & 26.0 & 2.35 & $6 \mathrm{I}, \mathrm{I}$ & 83.2 & 24.9 & 73.5 & 22.2 \\
\hline I 3.5 & 106.5 & $3 \cdot 3$ & 280 & 25.0 & 2.45 & 61.2 & 79.7 & 23.7 & 74.3 & 21.9 \\
\hline \multicolumn{2}{|c|}{ Average, } & $3 \cdot 3 I$ & & & & & 83.4 & $28 . I$ & 74.35 & $2 \mathrm{I} .9 \mathrm{I}$ \\
\hline I 4.5 & 106.5 & 3.6 & $35^{\circ}$ & 27.0 & 3.05 & 82.2 & 9 I. 2 & $25 \cdot 3$ & 84.9 & $23 \cdot 5$ \\
\hline I 5.0 & 102,5 & 4.0 & 360 & 24.5 & 3.05 & 74.8 & 88.0 & 24.9 & 76.3 & 20.9 \\
\hline I 5.6 & I06.5 & 4.2 & 380 & 26.0 & $3 \cdot 30$ & 85.7 & 85.0 & 24.4 & 78.6 & 22.5 \\
\hline I 5.5 & I I I. 5 & $4 \cdot 3$ & 390 & 27.0 & 3.25 & 87.7 & $8 \mathrm{I} .5$ & 24.2 & 75.2 & 22.5 \\
\hline 15.5 & 109.5 & $4 \cdot 5$ & 400 & 26.5 & $3 \cdot 4^{\circ}$ & 90.1 & $8 \mathrm{I} \cdot 3$ & 24.2 & 75.7 & 22.5 \\
\hline I 5.0 & I I0. 5 & $4 \cdot 4$ & 390 & 27.0 & 3.25 & 87 & 80.3 & 24.5 & 73.8 & 22.6 \\
\hline I 5.0 & 108.5 & 4.4 & 395 & 27.0 & 3.30 & 89.1 & 82.7 & 24.9 & $75 . I$ & 22.5 \\
\hline \multicolumn{2}{|c|}{ Average, } & 4.2 & & & & & $84 \cdot 3$ & 27.6 & $77 . I$ & 22.43 \\
\hline
\end{tabular}

The power factor began at an extremely low value of 36 percent, but rose very rapidly at first until a little over I.5 amperes A. C. had been reached, when it increased very slowly from then on, reaching 85 percent at the end. The current efficiency also began at a low value and rose quite rapidly, reaching a maximum of 84 percent at about I.5 amperes A. C., a little less than half the load. From this point it decreased very slowly to full load. The efficiency during the greater part of the run was quite good. 
The voltage efficiency was highest at the beginning of the run, and fell off very slightly as the current increased in value, dropping to 28 percent. The energy efficiency was also highest at the start and fell off slowly as the current rose. The energy efficiency is quite low because of the poor voltage efficiency. The variation of temperature during the run was slight, a rise of four degrees occurring. This was partly due to changes' in the temperature of the cooling water.

\section{Efficiency Run 2}

The conditions under which this run was taken were the same as those in the preceding run, except that the electrolyte had become contaminated with carbon. No carbon is able to withstand, for any length of time, the attack of any solution giving off oxygen, and while graphite will resist much longer than carbon, its life in such solutions is short. Before beginning the run, therefore, the electrolyte was removed and filtered so that most of the carbon particles were gotten rid of. The data are given in Table II.

TABLE II.

\begin{tabular}{|c|c|c|c|c|c|c|c|c|c|c|}
\hline \multirow[b]{2}{*}{ Temp. } & \multicolumn{3}{|c|}{ Alternating } & \multicolumn{3}{|c|}{ Direct } & \multicolumn{4}{|c|}{ Percent efficiency } \\
\hline & Volts & Amp. & Watts & Volts & Amp. & Watts & $\mathrm{P} f_{f}$ & V.E. & C. E. & E.E. \\
\hline $14.5^{\circ}$ & 102.0 & 0.73 & 39 & 50.0 & o. 6 & 8.0 & $52 \cdot 4$ & 49.0 & 21.9 & 20.5 \\
\hline 14.0 & 100.5 & 0.65 & 25 & $49 \cdot 5$ & 0.18 & 8.92 & 38.3 & 49.2 & 27.7 & $35 \cdot 7$ \\
\hline I 3.5 & IOI.O & 0.73 & 30 & 48.5 & 0.18 & 8.74 & 40.7 & 48.0 & 24.6 & 29.1 \\
\hline I 3.5 & 99.5 & 0.73 & 30 & 48.0 & 0.18 & 8.65 & $4 x \cdot 3$ & 48.2 & 24.6 & 24.8 \\
\hline $\mathrm{I} 3.2$ & IOI.5 & 0.68 & 25 & 48.5 & 0.17 & 8.25 & $3^{6.3}$ & 47.7 & 25.0 & 32.9 \\
\hline I $3 . I$ & IOO. 5 & 0.72 & 26 & 48.5 & O.I 8 & 8.74 & 35.9 & 48.2 & 25.0 & 33.6 \\
\hline I3.I & IOI. 5 & 0.74 & 29 & $49 \cdot 5$ & 0.19 & $9 \cdot 4$ & 38.6 & $4^{8.7}$ & 25.7 & 32.4 \\
\hline \multicolumn{2}{|c|}{ Average, } & $0.7 \mathrm{II}$ & & & & & $33 \cdot 3$ & 55.1 & 24.35 & 29.85 \\
\hline $\mathrm{I} 3 \cdot 2$ & I05.5 & 1.08 & $8 a$ & 42.0 & 0.62 & 26. I & 70.2 & 39.8 & 57.4 & 32.6 \\
\hline 13.0 & 103.7 & 1.08 & 82 & 41.0 & 0.70 & 28.7 & 72.3 & 39.5 & 64.7 & 35.0 \\
\hline 13.0 & 105.5 & $\mathrm{I} .08$ & 83 & 72.0 & 0.70 & 29.4 & 72.9 & 39.8 & 64.7 & 35.5 \\
\hline I 3.0 & 105.5 & 1.08 & 85 & 43.0 & 0.72 & 30.9 & 74.6 & 40.8 & 66.6 & $3^{6.4}$ \\
\hline 13.0 & 104.5 & 1.20 & 100 & 42.5 & 0.72 & 30.6 & 79.8 & 40.7 & 60.0 & 30.6 \\
\hline I 3.0 & 100.0 & 1.08 & 85 & 43.0 & 0.7 I & 30.5 & 78.7 & 43.9 & 65.7 & 36.0 \\
\hline I 3.0 & 106.5 & I. I 5 & 90 & 44.0 & 1.08 & 47.5 & 73.5 & $4 \mathrm{I} .2$ & 94.0 & 52.8 \\
\hline \multicolumn{2}{|c|}{ Average, } & I. 107 & & & & & 74.5 & 45.4 & 67.58 & 36.98 \\
\hline
\end{tabular}


TABLE II.-(Continued).

\begin{tabular}{|c|c|c|c|c|c|c|c|c|c|c|}
\hline \multirow[b]{2}{*}{ Temp. } & \multicolumn{3}{|c|}{ Alternating } & \multicolumn{3}{|c|}{ Direct } & \multicolumn{4}{|c|}{ Percent efficiency } \\
\hline & Volts & Amp. & Watts & Volts & Amp. & Watts & $\mathrm{Pf}_{f}$ & V.E. & C. E. & E. E. \\
\hline $13.0^{\circ}$ & 105.0 & 1.40 & I IO & $4 \mathrm{I}, \mathrm{O}$ & 0.96 & $39 \cdot 3$ & 74.9 & 39.1 & 68.6 & 35.7 \\
\hline I 3.0 & 106.0 & 1.40 & I IO & 41.0 & 0.96 & & 74.2 & 38.7 & 68.6 & $35 \cdot 7$ \\
\hline 13.0 & 105.5 & I. 62 & I 30 & 40.5 & 1.00 & & 76.0 & 38.4 & $6 \mathrm{r} .7$ & 3 I.I \\
\hline 13.0 & 104.0 & I. 55 & I 25 & 40.0 & 0.96 & & 77.6 & 38.5 & 62.0 & 30.7 \\
\hline 13.0 & 106.5 & I. 56 & I 30 & 40.5 & 0.96 & & 78.3 & 38. I & $6 . \mathrm{I} \cdot 5$ & 29.9 \\
\hline 13.0 & 106.0 & I. 56 & 130 & 0.0 & 0.97 & & 78.3 & 37.7 & 62.2 & 29.8 \\
\hline 13.0 & 105.5 & I. 62 & I 29 & 40.0 & 0.95 & 38.0 & 75.5 & 38.0 & 58.7 & $29 \cdot 4$ \\
\hline \multicolumn{2}{|c|}{ Average, } & I. 5.3 & & & & & 76.4 & 42.6 & 63.33 & 31.75 \\
\hline 13.0 & 105.5 & 2.4 & 200 & 36.0 & 1.70 & $6 \mathrm{I} .2$ & 79.0 & 34.1 & 70.8 & 30.6 \\
\hline 13 & 107.0 & 2.3 & I95 & 37.0 & I. 65 & 72.2 & 79.2 & 34.6 & 71 & 37.0 \\
\hline I 3 & 106.5 & 2.2 & 170 & 35.0 & $\therefore: 60$ & 56.0 & 72.5 & 32.9 & 72 & 32.1 \\
\hline & 106.0 & 2.3 & I 80 & 35.0 & I. 60 & 56.0 & 74.0 & 33.0 & 69.7 & $3 \mathrm{I}$. \\
\hline & 106.0 & 2.2 & I 80 & 35.0 & 1.60 & 56.0 & 77.2 & 330 & 72.8 & $3 \mathrm{I} .2$ \\
\hline & 105.5 & 2.2 & I 75 & 35.5 & I. $5^{8}$ & 56.2 & 754 & $33 \cdot 4$ & $7 \mathrm{I} .7$ & 32.1 \\
\hline I 3.5 & 105.5 & $2 . I$ & 170 & 35.0 & I. 55 & 54.2 & 76.5 & 33.2 & 73.8 & 31.9 \\
\hline \multicolumn{2}{|c|}{ Average, } & 2.213 & & & & & 76.2 & 36.8 & $7 \mathrm{I} .77$ & 32.28 \\
\hline I 3.5 & 106.0 & 3.0 & $25^{\circ}$ & 33.0 & 2.23 & 73.7 & 78.6 & 3I.I & 74.4 & $29 \cdot 5$ \\
\hline & 103.5 & 3.0 & 245 & 32.5 & 2.25 & & 78.8 & $3 \mathrm{I} .5$ & & $29 \cdot 7$ \\
\hline 14.0 & 107.0 & 3.2 & 298 & 34.0 & 2.35 & 80.0 & 87.2 & 31.8 & & 26.8 \\
\hline & 107.0 & 3.1 & 300 & 34.0 & 2.30 & 78.2 & 90.5 & 31.8 & & 26. I \\
\hline & 104.0 & 2.8 & 250 & 32.0 & 2.20 & & 86.0 & 308 & & 28. I \\
\hline & 107.0 & 3.2 & 280 & 35.0 & 2.28 & 79 & 81.9 & 32.7 & & 28.3 \\
\hline 14.0 & 106.5 & 3.0 & 275 & 34.0 & 2,28 & 77.5 & 86.2 & 31.9 & 76.0 & 28.2 \\
\hline \multicolumn{2}{|c|}{ Average, } & \multicolumn{2}{|l|}{$|3.042|$} & & & & $84 . \mathrm{I}$ & $35 \cdot 3$ & 74.7 & 28.1 \\
\hline 13.0 & IO3. 5 & 3.6 & 320 & 32.0 & 2.85 & & 85.7 & 30.9 & 79.2 & 28.5 \\
\hline & & 3.4 & 276 & 30.0 & 2.72 & & 81.6 & 30.2 & 80.0 & 29.6 \\
\hline & 104.0 & 3.7 & 320 & 32.0 & 2.85 & $9 x$ & 83.2 & 30.7 & 77 & 28.5 \\
\hline & & 3.5 & 280 & 30.5 & 2.70 & & 75.9 & 28.9 & 77 & 29.4 \\
\hline & IO & 3.5 & 320 & 30. & 2.82 & & & 28.7 & & 26.4 \\
\hline & & 3.4 & 30 & 33.0 & 2.70 & 89 & 83.5 & 30.7 & 79.5 & 29.2 \\
\hline I 5.0 & 108.5 & 3.7 & $35^{\circ}$ & 34.0 & 2.92 & 99.2 & 94.5 & 31.3 & 79.0 & 28.3 \\
\hline \multicolumn{2}{|c|}{ Average, } & 3.642 & & & & & 84.5 & 33.6 & 76.1 & 28.55 \\
\hline
\end{tabular}


TABLE II.-(Continued).

\begin{tabular}{|c|c|c|c|c|c|c|c|c|c|}
\hline \multirow[b]{2}{*}{ Temp. } & \multicolumn{3}{|c|}{ Alternating } & \multicolumn{3}{|c|}{ Direct } & \multicolumn{3}{|c|}{ Percent efficiency } \\
\hline & Volts & Amp. & Watts & Volts & Amp. & Watts & $\mathrm{P}_{f}$ & V. E. C. E. & E. E. \\
\hline I 4.0 & I05. 5 & 5.2 & 510 & 30.0 & 4. 10 & I 23 & 93.0 & 28.479 .0 & 24 \\
\hline I 5.8 & 104.5 & 5.5 & 535 & 30.0 & 4.30 & I 29 & 93.4 & 28.780 .4 & 23.5 \\
\hline 17.0 & 105.5 & 7.40 & 710 & 31.0 & 5.90 & 183 & 92.2 & 29.479 .8 & $25 \cdot 7$ \\
\hline I8.0 & 104.0 & 8.0 & $-\infty$ & 30.5 & 6.85 & 209 & -- & 29.385 .6 & \\
\hline \multicolumn{2}{|c|}{ Average, } & 6.7 & & & & & 92.8 & $32.3 \mid 8 \mathrm{I} .2$ & $24 \cdot 4^{8}$ \\
\hline
\end{tabular}

The run was begun with a direct current output of about o.I 8 ampere, and run up to about 5 amperes, when heating developed to such an extent and the fluctuations in current were so great that the run was cut short a little in order to avoid trouble.

The power factor begins at a very low value, but rises very quickly to about 80 percent and then continues to rise slowly to the end of the run, when its value is almost 93 percent. The current efficiency begins low and rises quickly to 70 percent, when it also increases slowly, reaching a value of a little over $8 \mathrm{r}$ percent at the end of the run. The voltage efficiency falls off rather rapidly until about half load when it is a little over 34 percent, and then falls slowly to the end of the run, reaching a value of a little over 32 percent. The energy efficiency falls off steadily during the run, ending at about 24.5 percent. The efficiencies obtained in Run 2 are higher than those in Run I, though the curves are quite alike in form. The temperature rose about $5^{\circ}$ from its lowest point, $4^{\circ}$ of this rise occurring in the last twenty minutes of this run.

\section{Efficiency Run 3}

By the time Run 2 was ended, the graphite electrodes had disintegrated to such an extent that it was impossible to use them any longer. Consequently, they were replaced by lead electrodes which occupied the same positions in the cell. The electrolyte was again filtered to remove the carbon particles, and when clean was put back into the cells. Everything else remained as before. The data are given in Table III. 
TABLE III.

\begin{tabular}{|c|c|c|c|c|c|c|c|c|c|c|}
\hline \multirow[b]{2}{*}{ Temp. } & \multicolumn{3}{|c|}{ Alternating } & \multicolumn{3}{|c|}{ Direct } & \multicolumn{4}{|c|}{ Percent efficiency } \\
\hline & Volts & Amp. & Watts & Volts & Amp. & Watts & $\mathrm{P} f_{f}$ & V. E. & C. E. & E. E. \\
\hline $17.0^{\circ}$ & 104.5 & 1.07 & 60 & 45.5 & 0.45 & 20.5 & 53.7 & 43.5 & 42. I & 34.2 \\
\hline I6.5 & 102.5 & 0.97 & 35 & 45.0 & 0.44 & 19.8 & $35 \cdot 5$ & 43.8 & 45.4 & 56.6 \\
\hline I 5.8 & 105.5 & 0.88 & 20 & 45.0 & 0.50 & 22.5 & $2 x .6$ & 42.7 & 56.8 & - \\
\hline I 5.5 & 105.5 & 0.92 & 20 & 45.0 & 0.50 & 22.5 & 20.6 & 42.7 & 54.4 & - \\
\hline I 5.0 & 102.5 & 0.97 & 35 & 44.0 & 0.54 & 23.8 & $35 \cdot 3$ & 42.9 & 58.8 & 68.0 \\
\hline 15.0 & 106.6 & 1.02 & 40 & 46.5 & 0.57 & 26.5 & 36.8 & $43 \cdot 7$ & 55.8 & 66.2 \\
\hline I 5.0 & 103.5 & 0.92 & 50 & $45 \cdot 5$ & 0.48 & 21.8 & 52.5 & 44.0 & 54.4 & 43.6 \\
\hline \multicolumn{2}{|c|}{ Average, } & 0.964 & & & & & 36.5 & 48.3 & $52 . I$ & 53.7 \\
\hline I 5.5 & 105.5 & I. 52 & 70 & 40.0 & I. I 5 & 46.0 & 43.7 & 38.0 & $75 \cdot 7$ & 65.7 \\
\hline I 5.5 & 102.5 & 1.38 & 80 & $3^{8.5}$ & I. I 5 & $44 \cdot 3$ & 56.5 & 37.7 & 83.4 & 55.5 \\
\hline I 5.5 & 104.0 & I. 42 & 90 & 39.5 & I. 25 & $49 \cdot 3$ & 60.9 & 38.0 & 88.I & 54.8 \\
\hline I 5.2 & IO4.0 & I. 46 & 70 & $39 \cdot 5$ & I. I 5 & 49.5 & 46. I & 38.0 & 79.8 & 65.2 \\
\hline I 5.0 & 108.0 & I. 42 & 80 & 4 I.O & I. 25 & $5 \mathrm{I} .2$ & $52 . \mathrm{I}$ & 38.0 & 88.1 & 64.0 \\
\hline I 5.0 & 105.5 & I. 50 & 85 & 40.5 & I. I 5 & $4 I .6$ & 53.6 & 38.4 & 76.7 & 48.9 \\
\hline I 5.0 & 100.0 & I. 46 & 85 & 38.0 & I. I 5 & $43 \cdot 7$ & 58.2 & 38.0 & 79.8 & 51.4 \\
\hline \multicolumn{2}{|c|}{ Average, } & I. $45 \mathrm{I}$ & & & & & 53.0 & 42.2 & $8 \mathrm{I} .5$ & 57.93 \\
\hline I 5.0 & I05. 5 & 2.30 & I 85 & 38.5 & 1.70 & 65.5 & 76.2 & 36.5 & 73.9 & 35.4 \\
\hline I 5.0 & 105.5 & 2.20 & I 80 & 37.0 & 1.65 & 6I.I & 77.6 & 35.5 & 75.0 & 33.9 \\
\hline I $5 . \mathrm{I}$ & 108.5 & 2.40 & 210 & 38.0 & I. 74 & 66.2 & 80.6 & 35.0 & 72.5 & 31.5 \\
\hline I 5.0 & 107.0 & 2.20 & 190 & 38.0 & 1.74 & 66.2 & 80.6 & 35.5 & 79.2 & 34.8 \\
\hline 15.0 & IO2. 5 & 2.40 & $2 \mathrm{IO}$ & 37.0 & I. 74 & 64.4. & 85.5 & 36.1 & 72.5 & 30.7 \\
\hline 15.0 & IO2. 5 & 2.20 & I 85 & 35.0 & 1.67 & 58.5 & 82.0 & 34.2 & 76.0 & 3 r. 6 \\
\hline I 5.0 & IO3. 5 & 2.30 & 190 & 36.0 & 1.60 & 57.5 & 80.0 & 34.8 & 69.7 & 30.3 \\
\hline \multicolumn{2}{|c|}{ Average, } & \multicolumn{2}{|l|}{2.285} & & 80.3 & 39.4 & $74 . \mathrm{I}$ & 32.6 \\
\hline I 5.0 & IOr. 5 & 3. 10 & 260 & 33.0 & 2.35 & 77.6 & 82.6 & 32.5 & 75.8 & 29.9 \\
\hline I 5.0 & 105.0 & 3.05 & 265 & 35.0 & 2.40 & 84.0 & 82.8 & $33 \cdot 3$ & 78.8 & $3 \mathrm{I} .7$ \\
\hline I 5.0 & 103.5 & 3.30 & 300 & 34.0 & 2.50 & 85.0 & 87.6 & 32.9 & 75.4 & 28.3 \\
\hline I 5.0 & 106.0 & 3.40 & $3+5$ & 34.5 & 2.50 & 86.2 & 87.2 & 32.5 & 73.6 & 27.4 \\
\hline I 5.0 & I06. 5 & 3.20 & 325 & 35.0 & 2.45 & 85.8 & 95.5 & 32.9 & 76.7 & 26.4 \\
\hline I 5.0 & IO7. 5 & 3.20 & 285 & 35.5 & 2.45 & 87.0 & 82.8 & 33. I & 76.7 & 30.5 \\
\hline I 5.0 & 105.5 & 3. 10 & 280 & 33.5 & 2.35 & 78.8 & 85.6 & 31.8 & 75.8 & 30.6 \\
\hline \multicolumn{2}{|c|}{ Average, } & 3.193 & & & & & 86.3 & 36.3 & 76.1 & 29.25 \\
\hline
\end{tabular}


TABLE III.-(Continued).

\begin{tabular}{|c|c|c|c|c|c|c|c|c|c|c|}
\hline \multirow{2}{*}{$\overline{T e m p}$} & \multicolumn{3}{|c|}{ Alternating } & \multicolumn{3}{|c|}{ Direct } & \multicolumn{4}{|c|}{ Percent efficiency } \\
\hline & Volts & Amp. & Watts & Volts & Amp. & Watts & $\mathrm{P} f_{f}$ & V. E. & C. E. & E. E. \\
\hline I 5.8 & IOI.O & 4.00 & 340 & 32.5 & 3.20 & 104.0 & 84.2 & 32.2 & 80.0 & 30.6 \\
\hline 16.0 & 103.5 & 4.00 & 350 & 32.0 & 3.05 & 97.5 & 84.5 & 30.9 & 76.3 & 27.9 \\
\hline I 6.0 & 105.0 & 4.00 & 360 & 32.0 & 3.10 & 99.2 & 85.8 & 30.5 & 77.6 & 27.5 \\
\hline I6.0 & 103.5 & 4. IO & 380 & 3 I. 5 & 3.20 & 100.7 & 89.5 & 30.4 & 78.0 & 26.7 \\
\hline 16.0 & 99.5 & 4.05 & 380 & 30.0 & 3.20 & 64.0 & 94.4 & 30.2 & $77 . \mathrm{I}$ & 24. I \\
\hline 16.0 & 104.5 & $4.20^{\circ}$ & 390 & $3 \mathrm{I} .5$ & 3.30 & 104.0 & 88.9 & 30.1 & 78.6 & 26.7 \\
\hline I6.0 & 107.5 & 4.20 & 385 & 32.5 & 3.25 & 105.5 & 91.5 & 30.2 & 77.4 & 27.4 \\
\hline \multicolumn{2}{|c|}{ Average, } & 4.078 & & & & & 88.4 & 33.5 & 77.85 & 27.27 \\
\hline I6.0 & I06.5 & 5.60 & $55^{\circ}$ & 30.5 & 4.25 & I 27.5 & 92.2 & 28.9 & 75.9 & 23.2 \\
\hline I 6.8 & I06.0 & 5.70 & 525 & 31.0 & 4.30 & I 33.2 & 87.0 & $29 \cdot 3$ & 75.5 & 25.4 \\
\hline 17.0 & IO2.5 & 6. 10 & 560 & 30.0 & 4.40 & I 32.0 & 89.8 & $29 \cdot 3$ & 72.2 & 23.6 \\
\hline 17.0 & I06.0 & 5.90 & 565 & $3 \mathrm{I} .0$ & $4 \cdot 30$ & I 33.2 & 90.4 & 29.3 & 72.9 & 23.6 \\
\hline 17.2 & 104.5 & 5.30 & 510 & 30.5 & 4. 5 & I 26.5 & $92 . \mathrm{I}$ & 29.2 & 78.3 & 24.8 \\
\hline 17.0 & I 05.5 & 4.80 & 435 & 30.5 & 3.65 & I I I. 5 & 85.0 & 28.9 & $76 . \mathrm{I}$ & 25.6 \\
\hline 16.0 & 98.0 & 5. 10 & 480 & 28.5 & 4.00 & I I 4.0 & 96.0 & 29. I & 78.5 & 23.8 \\
\hline \multicolumn{2}{|c|}{ Average, } & 5.50 & & & & & 90.3 & 32.4 & 75.63 & 24.25 \\
\hline I 6.0 & 100.5 & 6.60 & 590 & 28.0 & 5.00 & I 40.0 & 88.9 & 27.9 & 75.8 & 23.8 \\
\hline I 6.2 & 102.5 & 6.70 & 630 & 30.0 & 5.05 & I $5 \mathrm{I} .5$ & 91.7 & $29 \cdot 3$ & 75.4 & $24 . I$ \\
\hline 16.0 & 102.5 & 5.70 & 520 & 30.0 & 5.00 & I 50.0 & 89.0 & $29 \cdot 3$ & 87.8 & 28.9 \\
\hline 16.0 & 105.5 & 6.80 & 660 & 30.0 & 5.50 & I 65.0 & 92.0 & 28.4 & 80.9 & 25.0 \\
\hline I 6.0 & I 00.5 & 7.10 & 695 & $29 \cdot 5$ & 5.65 & I 66.8 & 97.5 & $29 \cdot 3$ & 79.6 & 24.0 \\
\hline I 6.0 & 103.0 & 6.90 & 660 & 30.0 & 5.32 & I 59.6 & 92.9 & $29 . \mathrm{I}$ & 77.2 & 24.2 \\
\hline I 6.0 & 103.0 & 6.80 & 635 & $29 \cdot 5$ & 5.05 & I 49.0 & 90.6 & 28.7 & 74.4 & 23.5 \\
\hline \multicolumn{2}{|c|}{ Average, } & 6.65 & & & & & 9 1. 8 & 32.2 & 78.7 & 24.8 \\
\hline 17.0 & IO2.5 & 8.30 & 790 & 29.0 & 6.70 & I 94. I & 93.0 & 28.3 & 80.8 & 24.6 \\
\hline 17.0 & 102.5 & 8.30 & 800 & 29.0 & $6.5^{\circ}$ & I 88.5 & 94.0 & 28.3 & 78.4 & 23.6 \\
\hline 17.0 & IO3. 5 & 7.70 & 725 & 29.3 & 6.00 & I 75.8 & 91.0 & 28.3 & 78.1 & $24 \cdot 3$ \\
\hline 17.0 & 102.5 & 8.00 & 750 & 28.5 & 6.25 & I 78.0 & 9 I.5 & 27.8 & $78 . I$ & 23.7 \\
\hline 17.0 & 100.0 & 8.00 & 760 & 27.0 & 6.40 & 173.0 & 95.0 & 27.0 & 80.0 & 22.8 \\
\hline \multicolumn{2}{|c|}{ Average, } & 8.06 & & & & & 92.9 & 3I.I & 79.1 & 23.8 \\
\hline
\end{tabular}

The run was begun with a direct current output of about 0.5 ampere and carried up to 6.4 amperes. The curves obtained 
begin at higher values and, in general, lie higher than those in Runs I and 2.

The power factor rises gradually from 36 percent at the start to 88 per cent at about half load, and then increases very slowly to full load reaching a value of nearly 93 per cent. The current efficiency rises from 52 .I percent at the lowest load to about 78 percent at half load, and then remains constant until the end of the run. The voltage efficiency, starting at 49 percent, fell off to 34 percent at half load, and then dropped off very slowly to the end of the run. The energy efficiency fell off fairly rapidly up to half load and then decreased slightly to full load. In this run the current carried was somewhat in excess of that in either of the two previous runs. The temperature changed very gradually and finally reached a point at the end of the run only two degrees above the lowest point.

\section{Efficieney Run 4.}

The conditions in this run were exactly the same as in Run 3; the current, however, reached a much larger value, Table IV. TABLE IV.

\begin{tabular}{|c|c|c|c|c|c|c|c|c|c|c|}
\hline \multirow[b]{2}{*}{ Temp. } & \multicolumn{3}{|c|}{ Alternating } & \multicolumn{3}{|c|}{ Direct } & \multicolumn{4}{|c|}{ Percent efficiency } \\
\hline & Volts & Amp. & Watts & Volts & Amp. & Watts & $\mathrm{P} f$ & V. E. & C. E. & E. E. \\
\hline $16.0^{\circ}$ & IO9.0 & 0.98 & 65 & 49.0 & 0.55 & 26.9 & $60 ; 8$ & 44.9 & 56. I & $4 \mathrm{I} .5$ \\
\hline I $5 \cdot 5$ & I 10.5 & 1.00 & 70 & 50.0 & 0.55 & 27.5 & 63.4 & 45.2 & 55.0 & $39 \cdot 3$ \\
\hline I 5.0 & 108.0 & I.O4 & 75 & 49.0 & 0.56 & 27.4 & 66.6 & $45 \cdot 4$ & 53.8 & 36.5 \\
\hline I 5.0 & I08. 5 & I.08 & 80 & 50.0 & 0.57 & 28.5 & 68.3 & $46 . I$ & 52.7 & 35.7 \\
\hline 15.0 & 107.5 & I.04 & 75 & 49.0 & 0.56 & 27.4 & 67.0 & 45.6 & 53.8 & 36.5 \\
\hline 15.0 & 108.5 & 0.98 & 68 & 49.0 & 0.55 & 26.9 & 64.0 & 45.2 & 56.1 & 39.6 \\
\hline 15.0 & 107.5 & I.O4 & 68 & 47.5 & 0.55 & 26. I & 60.8 & $44 \cdot 2$ & 52.9 & 38.4 \\
\hline \multicolumn{2}{|c|}{ Average, } & 1.02 & & & & & 64.4 & 50.4 & 54.2 & 38.2 \\
\hline I 6.0 & 108.5 & 3.0 & 265 & 41.0 & 2.20 & 90.2 & $8 \mathrm{I} .5$ & 37.8 & $73 \cdot 3$ & $34 . \mathrm{I}$ \\
\hline 15.8 & $\mathrm{r} 05.5$ & 2.7 & 230 & 39.0 & 2. I 5 & 84.0 & 87.2 & 37.0 & 79.7 & 36.5 \\
\hline 15.8 & 106.0 & 2.8 & 265 & 39.5 & 2.20 & 87.0 & 89.0 & $37 \cdot 3$ & 78.6 & 32.8 \\
\hline 16.0 & 105.5 & 3.0 & 275 & 39.0 & 2.40 & 93.6 & 87.0 & 37.0 & 80.0 & 34. I \\
\hline 16.0 & I 07.5 & 2.7 & 230 & 39.0 & 2. I 5 & 84.0 & 79.2 & 36.3 & 79.7 & 36.8 \\
\hline 15.5 & IO 5.5 & 2.8 & 275 & 37.5 & 2. I 5 & 80.7 & 93. I & 35.5 & 76.7 & 29.4 \\
\hline I 5.5 & I05. 5 & 2.7 & 235 & 37.0 & 2.10 & 77.9 & 82.5 & 35.1 & 77.8 & 33.I \\
\hline \multicolumn{2}{|c|}{ Average, } & $2.8 \mathrm{I}$ & & & & & 85.3 & 40.8 & 78.0 & 33.3 \\
\hline
\end{tabular}


TABLE IV.-(Continued).

\begin{tabular}{|c|c|c|c|c|c|c|c|c|c|c|}
\hline \multirow[b]{2}{*}{ Temp. } & \multicolumn{3}{|c|}{ Alternating } & \multicolumn{3}{|c|}{ Direct } & \multicolumn{4}{|c|}{ Percent efficiency } \\
\hline & Volts & Amp. & Watts & Volts & Amp. & Watts & $\mathrm{P} f_{f}$ & V. E. & C. E. & E. E. \\
\hline 16.0 & I07.5 & $4 \cdot 5$ & 450 & 36.5 & 3.70 & I 35 & 93.2 & 34.0 & 82.2 & 30.0 \\
\hline 16.2 & 107.0 & 4.0 & 380 & 36.5 & 3.40 & I 24 & 88.5 & 34. I & 85.0 & 32.7 \\
\hline I 6.2 & I08. 5 & $4 \cdot 4$ & 430 & 36.5 & $3 \cdot 35$ & I 22 & 9o.I & $33 \cdot 7$ & 76.1 & 28.5 \\
\hline I6. I & 107.5 & $4 \cdot 4$ & 440 & 36.0 & 3.40 & 123 & 93.0 & $33 \cdot 5$ & $77 \cdot 3$ & 27.9 \\
\hline I6. I & 105.5 & $4 \cdot 2$ & 380 & 35.0 & 3.23 & II 3 & 85.8 & 33.2 & 76.9 & 29.8 \\
\hline 16.0 & 107.5 & $4 \cdot 3$ & 400 & 35.5 & $3 \cdot 30$ & I I 7 & 86.5 & 33.0 & 76.7 & 29.3 \\
\hline I6.0 & 106.5 & 4.2 & 370 & $35 \cdot 5$ & 3.25 & I I 6 & 82.6 & 33.3 & $77 \cdot 5$ & $3 \mathrm{I} .2$ \\
\hline \multicolumn{2}{|c|}{ Average, } & $4 \cdot 3$ & & & & & 88.5 & 38.7 & 78.8 & 29.9 \\
\hline I 5.0 & 104.5 & 5.8 & 560 & $3 I .5$ & 4.45 & I 40 & $9^{2.5}$ & 30.1 & 76.7 & 25.0 \\
\hline 16.0 & 103.5 & 5.4 & $5^{10}$ & 31.5 & $4 \cdot 30$ & I36 & 9 I. 2 & 30.4 & 79.7 & 26.6 \\
\hline 16.0 & IO 4.5 & 5.5 & 550 & 3 I. 5 & 4.45 & I 40 & 95.8 & 30.1 & $8 \mathrm{I.O}$ & 25.5 \\
\hline I6.0 & IO3. 5 & $5 \cdot 3$ & 505 & 30.5 & 4.25 & I 30 & 92.0 & 29.5 & 80.3 & 25.7 \\
\hline 16.0 & IO3.0 & 5.2 & 495 & 29.5 & 4. I 5 & I 22 & 92.4 & 28.7 & 79.8 & 24.7 \\
\hline 16.0 & 104.5 & 5.7 & 465 & 28.5 & 4.40 & 126 & 78. I & $27 \cdot 3$ & 77.2 & 27.0 \\
\hline 16.0 & ro5.5 & 5.7 & 495 & 31.0 & 4.39 & I 36 & 82.3 & 29.3 & 77.1 & 27.7 \\
\hline \multicolumn{2}{|c|}{ Average, } & $5 \cdot 5$ & & & & & 89.4 & $34 \cdot 3$ & 77.7 & 26.0 \\
\hline I 7.0 & IOI. 5 & $7 \cdot 5$ & 700 & 27.5 & 6.05 & 167 & 92.0 & $27 . I$ & 80.7 & 23.8 \\
\hline I 7.5 & 105.5 & 8.3 & 830 & 29.5 & 6.40 & I89 & 94.7 & 27.9 & 77.3 & 22.7 \\
\hline I 8.0 & I06.0 & 8.3 & 850 & 30.0 & 6.50 & I95 & 96.7 & 28.3 & 78.5 & 22.9 \\
\hline I 8.0 & 103.5 & 8. I & 8 I 5 & 28.0 & 6.50 & 182 & 97.1 & $27 . I$ & 80.3 & 22.3 \\
\hline I 8.0 & I06.0 & 8.0 & 800 & 30.5 & 6.35 & I94 & $94 \cdot 3$ & 28.3 & 79.5 & 24.2 \\
\hline I 8.0 & 105.5 & 8.3 & 8 I 5 & 30.0 & 6.40 & I92 & 93.0 & 28.4 & 77.2 & 23.5 \\
\hline I8.0 & 105.5 & 8. I & 800 & 30.0 & 6.25 & r 88 & 94.3 & 28.4 & 77.7 & 23.5 \\
\hline \multicolumn{2}{|c|}{ Average, } & 8. I & & & & & 94.5 & $3 I .2$ & 78.7 & $23 \cdot 3$ \\
\hline I 9.0 & 103.5 & I I.9 & I I 90 & 27.5 & 9.20 & 253 & 96.6 & 26.6 & 77.3 & $2 I .3$ \\
\hline 20.0 & 104.0 & I I. 8 & I I 80 & 27.5 & $9 \cdot 35$ & 277 & 96.0 & 26.4 & $79 \cdot 3$ & 23.5 \\
\hline 20.0 & 102.5 & $\mathrm{I} 2.4$ & $I 230$ & 27.5 & 9.65 & 265 & 96.9 & 26.8 & 77.8 & $2 \mathrm{I} .5$ \\
\hline 20.5 & 103.0 & & I I 60 & 27.0 & 9.35 & 253 & 93.8 & 26.2 & 77.9 & $2 \mathrm{I} .9$ \\
\hline 20.5 & IOI. 5 & I I. 8 & I I 50 & 27.0 & $9 \cdot 35$ & 253 & 96.0 & 26.6 & 79.2 & $22 . I$ \\
\hline 21.0 & IOI. 5 & I 2.3 & 1230 & 27.0 & 9.60 & 259 & 98.5 & 26.6 & 78.0 & $2 \mathrm{I} . \mathrm{O}$ \\
\hline 21.5 & 104.0 & 12.3 & I 240 & 27.5 & 9.50 & $26 \mathrm{I}$ & 97.0 & 26.4 & 77.3 & 20.9 \\
\hline s & & I 2.1 & & & & & 96.4 & 29.9 & $78 . \mathrm{I}$ & 21.7 \\
\hline
\end{tabular}



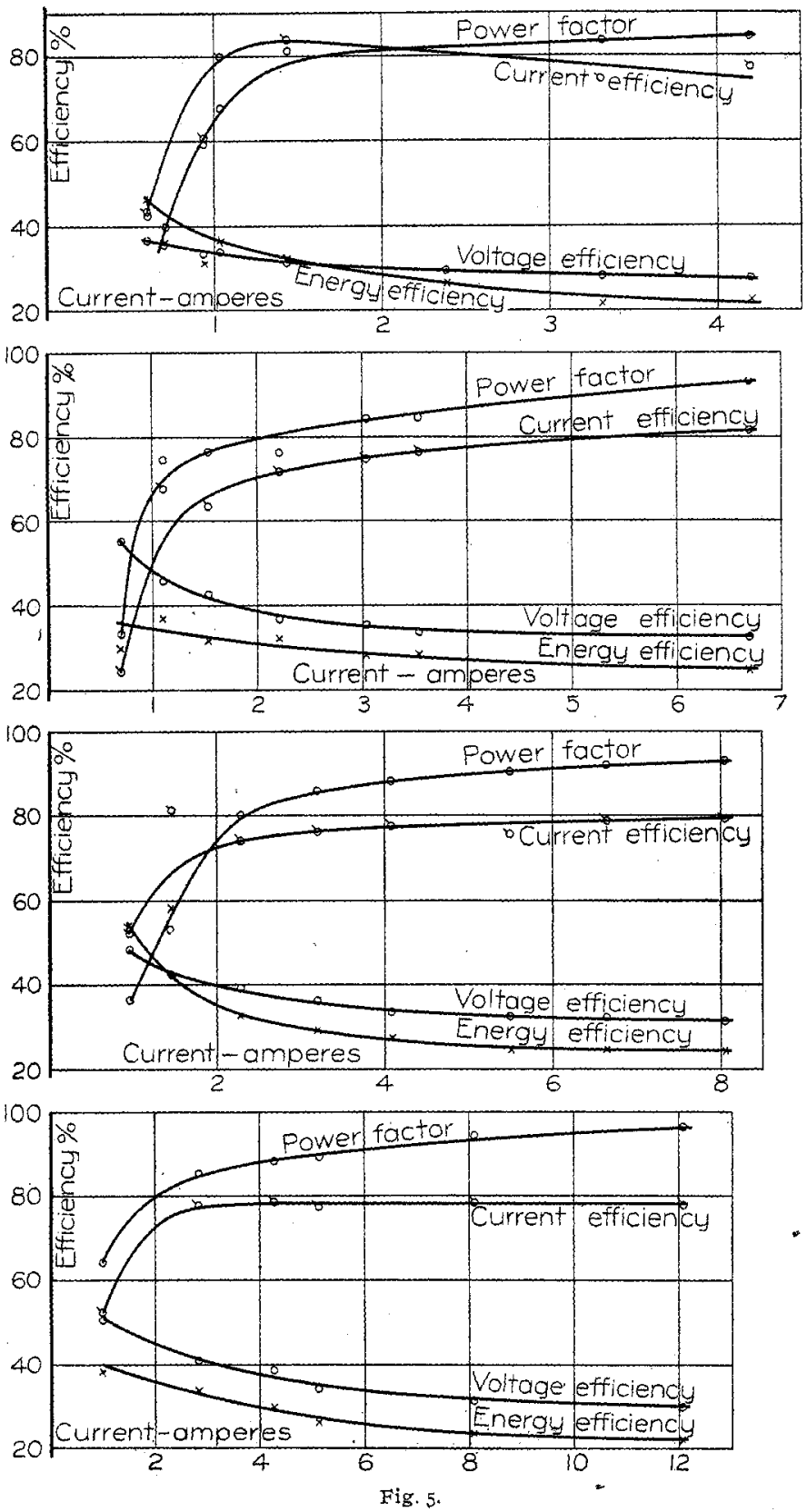
The power factor rose rapidly at first from its starting point at 64 percent, and then increased more slowly toward the end, reaching a value of 96.4 percent. The current rose rapidly just at the start, and then, as in the previous run, remained constant during the greater part of the run, at 79 percent. The voltage efficiency fell off in the usual way from $5^{\mathrm{I}}$ percent at the start to 30 percent at the end.

The current carried in this run was quite heavy, over I2 amperes on the alternating current side. In spite of this, the tubes, when examined, showed no signs of wear whatever, and were apparently in as good condition as when they were first put into operation, indicating that the life of the tube under ordinary conditions would be quite long. The results of the four runs are shown graphically in Fig. 5, the abscissas being amperes on the alternating current side.

\section{Efficiency Runs 5 and 6.}

After making the runs already discussed, it was decided to try an experiment. Half the electrolyte was removed, and its place was taken by sulphuric acid of sp. gr. I.2. As the critical pressure of sulphuric acid is about 65 volts, the run was made on 55 volts.

All the previous runs had been made on IIO volts, and to obtain 55 volts it was necessary to put in another transformer. This was done and the runs were taken as before, except that their duration was somewhat shorter.

Run 5. This run was begun at a direct current output of 0.5 ampere, and carried to an output of 5 amperes. The data are given in Table V. The power factor rose steadily from 66 percent to 93 per cent. The current efficiency rose from 55 percent at the start to 80 percent at about half load, and then fell off slightly to the end of the run. The voltage efficiency ran down steadily from 32 percent to 23 percent. The energy efficiency fell off to 17 percent at the end of the run, the lowest value yet reached.

Run 6. This was similar in all respects to Run 5, but was carried a trifle further. The data are given in Table VI. 
TABLE $V$

\begin{tabular}{|c|c|c|c|c|c|c|c|c|c|c|c|}
\hline \multirow[b]{2}{*}{ Temp. } & \multicolumn{3}{|c|}{ Alternating } & \multicolumn{3}{|c|}{ Direct } & \multicolumn{4}{|c|}{ Percent efficiency } & \multirow[b]{2}{*}{ Drop } \\
\hline & Volts & Amp. & Watts & Volts & Amp. & Watts. & $\mathbf{P}_{f}$ & V. E. & C. E. & E. E. & \\
\hline $17.0^{\circ}$ & $53 \cdot 5$ & I. 54 & 65 & I6. 5 & 0.95 & I 5.7 & 78.8 & $34 \cdot 3$ & $6 \mathrm{I} .7$ & 24.4 & 6.0 \\
\hline 17.0 & 54.0 & 1.08 & 30 & I 8.0 & 0.56 & IO.I & $5 \mathrm{I} .4$ & $|36.3|$ & 51.9 & 33.7 & 6.5 \\
\hline 17.0 & 53.5 & 1.08 & 45 & I $5 \cdot 5$ & $0.6 \mathrm{I}$ & $9 \cdot 45$ & 78.0 & 32.3 & 56.5 & 21.0 & 6.5 \\
\hline I 6.5 & $53 \cdot 5$ & 1.05 & 40 & I 3.0 & 0.55 & 5.2 & 69.3 & $2 \% . I$ & 52.4 & I 3.0 & 7.0 \\
\hline 16.5 & $52 \cdot 5$ & 0.97 & 25 & I6.5 & $0.5^{\circ}$ & 8.25 & 49.5 & 34.9 & 51.6 & 33.0 & 9.0 \\
\hline I6. $5^{\circ}$ & 53.5 & I. .08 & 40 & I5.5 & 0.60 & $9 \cdot 30$ & 69.4 & 32.2 & $55 \cdot 5$ & $23 \cdot 3$ & 8.0 \\
\hline \multicolumn{2}{|c|}{ Average, } & I. I 3 & & & & & 66.06 & 632.85 & 54.93 & 24.73 & 7.16 \\
\hline 17.0 & $52 \cdot 5$ & 2.5 & 100 & 12.0 & 1.9 & 23.8 & 76.2 & 25.4 & 76.0 & 23.8 & $5 \cdot 5$ \\
\hline $\mathrm{I} 7.0$ & 52.5 & 2.9 & IIO & 13.0 & 2. I & $27 \cdot 3$ & 72.4 & 27.5 & 72.5 & 24. & 6.0 \\
\hline 17.0 & $5 \mathrm{I} \cdot 5$ & 3.0 & I08 & I 2.5 & 2.0 & 25.0 & 70.0 & 27.0 & 66.8 & 22.2 & 6.0 \\
\hline I 7.0 & 53.5 & 2.8 & IO5 & 13.0 & 2.0 & 26.0 & 70.1 & 27.0 & $7 \mathrm{I} .5$ & 24.7 & 5.5 \\
\hline I 7.2 & 54.5 & 3.0 & $\mathrm{I} 2 \mathrm{O}$ & 13.0 & 2.2 & 28.6 & $73 \cdot 4$ & 26.6 & 73.4 & 23.8 & 6.0 \\
\hline I 8.0 & 53.0 & 2,5 & 95 & 12.0 & 1.9 & 23.8 & $\| 71.6$ & 25.2 & 76.1 & 25.1 & 7.0 \\
\hline \multicolumn{2}{|c|}{ Average, } & \multicolumn{2}{|l|}{2.783} & & & & 72.3 & 26.45 & \multicolumn{2}{|c|}{72.7 I 24.06} & 6.0 \\
\hline I 8.0 & 52.0 & $3 \cdot 4$ & $I_{50}$ & I 2.0 & 2.75 & 33.0 & 85.0 & 25.5 & 80.8 & 22.0 & 6.5 \\
\hline I 8.2 & 5 I. 5 & 3.5 & I 45 & I 2.0 & 2.90 & 34.8 & 80.5 & 25.9 & 82.8 & 24.0 & 6.5 \\
\hline I 8.0 & 52.5 & 3.6 & I 55 & 13.0 & 3.00 & 39.0 & 82.0 & 27.5 & $83 \cdot 3$ & $25 . \mathrm{I}$ & 6.2 \\
\hline 18.0 & $5 \mathrm{I} .5$ & 4.0 & 170 & $\mathrm{I} 4 . \mathrm{O}$ & 3.1 & 43.4 & 82.5 & 32.0 & 77.5 & 25.5 & 6.5 \\
\hline I 8.0 & $5 \mathrm{I} \cdot 5$ & 4.0 & I 55 & I 3.5 & $3 . I$ & 41.9 & 75.5 & 29.2 & 77.5 & 27.1 & 6.5 \\
\hline 18.2 & $5 x \cdot 5$ & 3.7 & $x_{40}$ & I 3.0 & 2.95 & 38.4 & 78.5 & $28 . \mathrm{I}$ & 79.7 & 27.4 & 6.5 \\
\hline \multicolumn{2}{|c|}{ Average, } & 3.7 & & & & & 80.66 & 528.0 & 80.26 & 26.2 & 6.44 \\
\hline I 8.2 & 50.5 & 6.9 & 320 & 10.5 & 5.50 & 57.7 & 89.0 & 23.1 & 79.8 & I 8.05 & 5.0 \\
\hline 20.2 & 48.5 & 6.7 & 312 & 10.0 & 5.25 & 52.5 & 96.0 & 22.9 & 78.3 & ¡ 6.85 & 5.0 \\
\hline 20.0 & 50.5 & 6.5 & $3 \mathrm{IO}$ & I0.9 & $5 . \mathrm{IO}$ & 55.5 & 94.5 & 24.9 & 78.5 & I 7.9 , & 5.0 \\
\hline 20.0 & $49 \cdot 5$ & 5.8 & 360 & 9.5 & 4.70 & $44 \cdot 5$ & - & $2 \mathrm{I} .3$ & 8 I. I & 12.4 & 5.0 \\
\hline 19.0 & 48.5 & 6.0 & $25^{\circ}$ & IO.O & 4.85 & $4^{8.5}$ & 86.0 & 22.9 & 80.8 & 19.4 & 5.0 \\
\hline 19.0 & 50.5 & 6.4 & 285 & 10.5 & 5.00 & 52.5 & 96.0 & $23 . I$ & $78 . \mathrm{I}$ & I 8.4 & 5.0 \\
\hline I9.0 & $50.0^{\circ}$ & 6.3 & 310 & I0.5 & 4.90 & 51.5 & 98.5 & 23.3 & 77.8 & I 6.6 & 5.0 \\
\hline Avera & & 37 & & & & & & 23.07 & 79.2 & 77.08 & 5.0 \\
\hline
\end{tabular}


TABLE VI

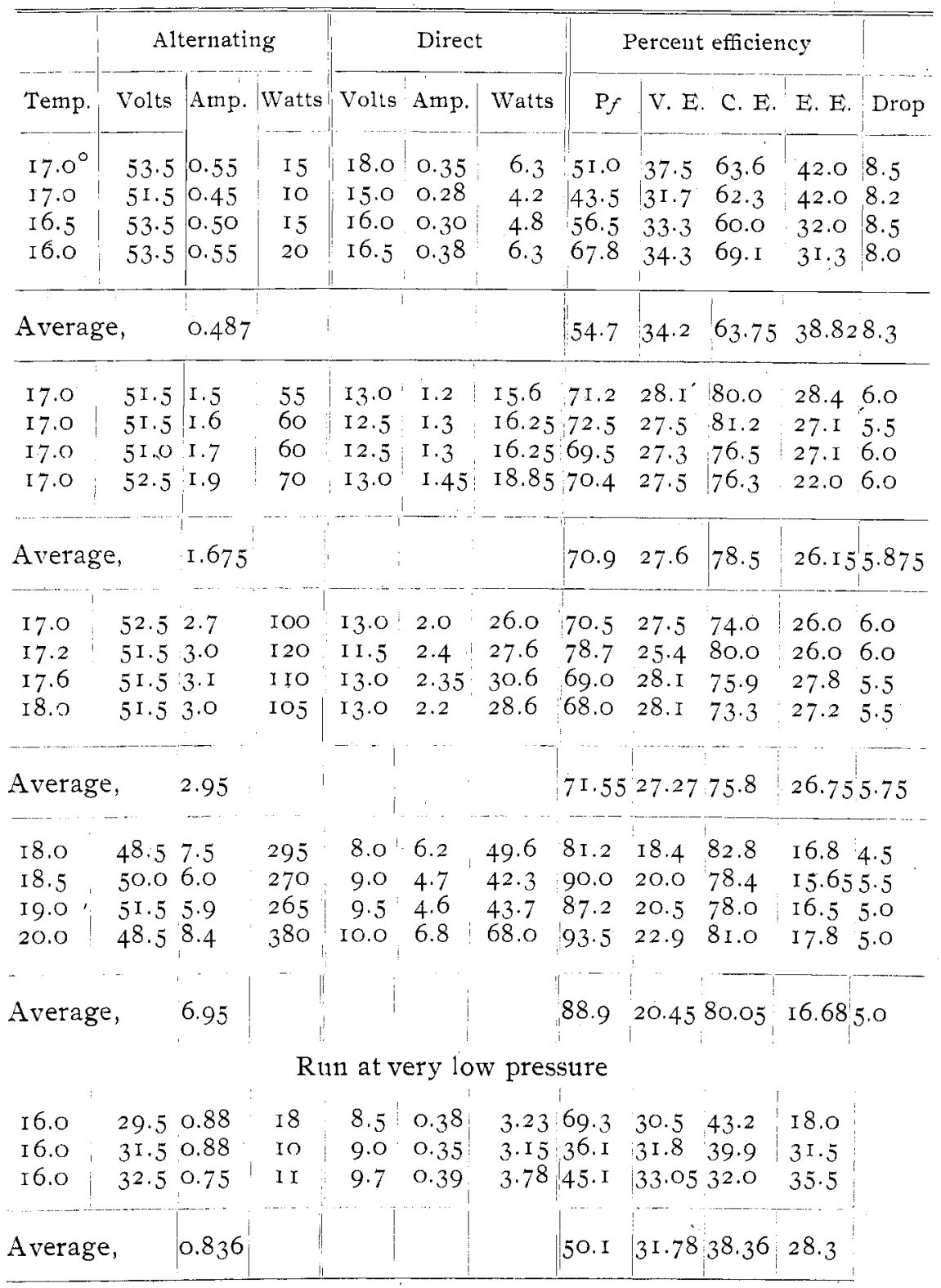


The power factor is lower, reaching only 89 percent. The current efficiency rose from 63 percent to 78 percent and then very slowly to 80 percent. The voltage efficiency fell off steadily from the start, and the energy efficiency dropped to I6.7 percent, the lowest obtained.

The last run was very short, owing to the fact that the temperature began to rise very rapidly toward the end.

In both runs the efficiencies obtained were, in general, lower than those obtained in the first four runs. It was further found, on examining the tubes, that the sulphuric acid had corroded the tubes so much that they were practically useless for further work. It was found on trial with the pressure at I Io volts and the electrolyte phosphoric acid, that the tubes could not be made to work, and so the investigation was stopped at this point.

Some of these results were quite unexpected. A leakage current would of course account for a low current efficiency at low current; but it is very surprising to find the current efficiency rising rapidly to about 80 percent in all the runs and then remaining practically constant. So long as one assumes the existence of mechanical valves a heavy leakage current is not unreasonable; but we do not believe in valves any more. We have not yet had time to make tests on the influence of depolarizers on the current efficiency, but we hope to do this before long and also to determine the wave forms of the current entering and leaving the rectifier.

The low energy efficiency is due to the low voltage efficiency. The internal resistance of the rectifier was not determined. An examination of the current-voltage curve shows that this is not a straight line. We have therefore a changing resistance, a changing electromotive force or both. The loss in voltage cannot be due solely to the internal resistance of the rectifier, this being not over a few ohms. There is apparently a counterelectromotive force which increases with increasing current and which has a value of $50-60$ volts'

${ }^{1} \mathrm{Cf}$. Isenburg: Zeit. Elektrochemie, 9, 278 ( 1903 ). 
The general results of this paper are:

I. Water-cooled aluminum electrodes in a phosphoric acid solution are satisfactory mechanically.

2. A current efficiency of $75^{-80}$ percent can easily be obtained over a fairly wide range of current.

3. Under the conditions of the tests, the voltage efficiency of the aluminum rectifier may be taken as $30-35$ percent and the energy efficiency as $20-30$ percent.

4. With increasing load the power factor rises rapidly to above 90 percent.

5. The chief cause of the voltage loss is not the internal resistance of the rectifier. The results can be explained by assuming a connterelectromotive force increasing with the current and having a value of $50-60$ volts over part of the range studied.

This work has been carried out under the supervision of Prof. Bancroft. My thanks are also due to Messrs. Carveth and Mott for suggestions and to the Department of Electrical Engineering for the loan of instruments.

Cornell University. 